\title{
CMV pp65 and IE-I T cell epitopes recognized by healthy subjects
} Stefanie L Slezak, Maria Bettinotti, Silvia Selleri, Sharon Adams, Francesco M Marincola and David F Stroncek*

\begin{abstract}
Address: Department of Transfusion Medicine, Warren G. Magnuson Clinical Center National Institutes of Health, Bethesda, Maryland, USA Email: Stefanie L Slezak - sslezak@cc.nih.gov; Maria Bettinotti - maria.p.bettinotti@questdiagnostics.com; Silvia Selleri - selleris@cc.nih.gov; Sharon Adams - sadams1@cc.nih.gov; Francesco M Marincola - fmarincola@cc.nih.gov; David F Stroncek* - dstroncek@cc.nih.gov

* Corresponding author
\end{abstract}

Published: 28 March 2007

Journal of Translational Medicine 2007, 5:17 doi:10.1186/1479-5876-5-17
Received: 9 January 2007

Accepted: 28 March 2007

This article is available from: http://www.translational-medicine.com/content/5/I/17

(c) 2007 Slezak et al; licensee BioMed Central Ltd.

This is an Open Access article distributed under the terms of the Creative Commons Attribution License (http://creativecommons.org/licenses/by/2.0), which permits unrestricted use, distribution, and reproduction in any medium, provided the original work is properly cited.

\begin{abstract}
Background: Adoptive immune and vaccine therapies have been used to prevent cytomegalovirus (CMV) disease in recipients of hematopoietic progenitor cell transplants, but the nature of $\mathrm{T}$ cell responses to CMV have not been completely characterized.

Methods: Peptide pools and individual peptides derived from the immune-dominant CMV proteins PP65 and IE-I and antigen-specific, cytokine flow cytometry were used to characterize the prevalence and frequency of CD4+ and CD8+ memory T cells in 20 healthy CMV-seropositive subjects.

Results: CD8+ T cell responses to pp65 were detected in $35 \%$ of subjects and to IE-I in $40 \%$ of subjects. CD4+ T cell responses to pp 65 were detected in $50 \%$ of subjects, but none were detected to IE-I. Several new IE-I HLA class I epitopes were identified, including 4 restricted to HLA-C antigens. One region of IE-I spanning amino acids 300 to 327 was rich in class I epitopes. The HLA class I restrictions of IE-I peptides were more promiscuous than those of pp65 peptides.

Conclusion: Since naturally occurring CD4+ and CD8+ T cell responses to pp65 were detectable in many subjects, but only CD8+ T cell responses to IE-I were detected, Pp65 may be better than IE-I for use in vaccine and adoptive immune therapies.
\end{abstract}

\section{Background}

Cytomegalovirus (CMV) is a persistent virus in normal hosts in which primary infection is typically controlled through a combination of adaptive and innate immune responses. Viral latency follows primary infection and continues for life, usually without major symptoms. Although $60 \%$ to $80 \%$ of adults that test seropositive for CMV antibodies show no symptoms of infection, in immunocompromised hosts, such as patients undergoing hematopoietic stem cell transplantation (HSCT) or recipients of organ transplants, CMV can cause severe dis- ease[1]. In the past 10 years, the incidence of CMV disease in allogeneic HSCT recipients during the first 100 days after transplantation fell from $40 \%$ to $5 \%$ as a result of improved diagnosis and prophylactic or preemptive treatment with antiviral drugs. However, the effect of the improved therapy has delayed disease onset to 6 to 12 months after transplantation, and the risk of severe CMV disease remains in $10 \%$ of allogeneic HSCT recipients[2].

In order to control rather than delay the incidence of $\mathrm{CMV}$ disease after HSCT, the host's anti-CMV immunity must 
be restored. Because CMV immunotherapy is growing in importance, the study of the immune response to CMV is clinically relevant. T cell immunity is believed to be the most important component in immune response to CMV disease. This is supported by the fact that Natural Killer cells recover early after HSCT, before the peak incidence of $\mathrm{CMV}$ disease, and by the failure of infusion of immunoglobulin (Ig) preparations containing antiviral antibodies to control the disease $[3,4]$. In contrast, clinical trials involving adoptive transfer of CMV-specific T cells were successful in restoring immunity against the virus $[5,6]$. An alternative to adoptive immunotherapy is vaccination of HSCT donors against CMV with the aim of providing specific immunity to the recipient for protection against primary infection or reactivation[7].

Two CMV proteins, phosphoprotein 65 (pp65) and immediate early protein-1 (IE-1), have been found to be major targets of the cellular immune response [8-12]. Immunodominant epitopes in these proteins have been defined for some human leukocyte antigen (HLA) alleles, but further definition for specific major-histocompatibility complex (MHC) classes and HLA allelic restrictions could be useful for adoptive immune therapy, vaccine therapy, and in screening for reactivation after immunosuppression $[13,14]$.

The purpose of this study was to characterize the natural repertoire of immunodominant pp65 and IE-1 epitopes in $20 \mathrm{CMV}$-seropositive, healthy subjects. Donor CD4+ and CD8+ T cell responses to CMV pp65 and IE-1 15-mer peptide libraries were defined and followed downstream to the individual 15-mer and nanomer peptides, respectively. This process identified epitopes without biases introduced by focusing on specific immunodominant regions for individual HLA types.

\section{Methods}

\section{Study design}

In this study, $20 \mathrm{CMV}$-seropositive and $5 \mathrm{CMV}$-seronegative healthy donors were evaluated. To determine the CD8+ and CD4+ T cell responses to CMV in the 25 donors, peripheral blood mononuclear cells (PBMCs) were stimulated in vitro with a cocktail of 15-mer peptides overlapping by 11 residues and covering the pp65 and IE1 proteins. Antigen-specific cytokine flow cytometry was used to detect specific $T$ cell responses[15,16]. To define immunodominant epitopes, PBMCs were also stimulated with subpools of pp65 and IE-1, each subpool containing 10 overlapping 15 -mer peptides. PBMCs reactive to a subpool were then tested further against the individual peptides contained within the subpool to determine the reactive $15-\operatorname{mer}(\mathrm{s})$. In order to further characterize epitopes presented to CD8+ T cells by HLA class I antigens, PBMCs from donors with reactive CD8+ cells were tested again with nanomer peptides spanning the reactive 15 -mer peptide and overlapping at 8 amino acids (Figures 1 and 2). These studies were approved by a National Institutes of Health Institutional Review Board on the use of Human Subjects in Research.

\section{Collection of PBMCs}

PBMC concentrates from $20 \mathrm{CMV}$-seropositive and 5 CMV-seronegative healthy donors were collected by apheresis, (Fenwal CS-3000 Plus, Baxter Healthcare Corp, Deerfield, IL) and peripheral blood mononuclear cells were isolated by ficoll-hypaque density gradient separation and frozen in aliquots of $1 \times 10^{8}$ cells. Donors were typed for HLA class I and class II alleles using sequencespecific primers and, in some cases, direct sequencing (HLA Laboratory, DTM, CC, NIH, Bethesda, MD). The presence of IgG and IgM CMV antibodies in each subject was analyzed by passive agglutination (BD, Microbiological Systems, Cockeysville, MD).

\section{Peptide libraries and pools}

Libraries for CMV proteins pp65 and IE- 1 were made up of peptides 15 amino acids long that overlapped by 11 residues and covering the complete pp65 (CMV Towne) [17] and IE-1 (CMV AD169) proteins[18]. The pp65 library was made up of 138 peptides and the IE-1 library of 120 peptides, and both were commercially synthesized (Princeton Biomolecules, Langhorne, PA). Peptides were diluted in dimethyl sulfoxide and pooled into cocktails containing the complete pp 65 and IE- 1 protein sequences and into subpools containing 10 consecutive peptides each. Pp65 was divided into 13 subpools of 10 peptides and 1 subpool of 8 peptides, and IE- 1 was divided into 12 subpools of 10 peptides (Figures 1 and 2).

\section{PBMC stimulation and flow cytometric assessment}

$\mathrm{T}$ cell activation was assessed by measuring intracellular interferon gamma (IFN- $\gamma$ ) production by flow cytometry after PBMC stimulation. PBMCs were plated at $1-5 \times 10^{6}$ per $\mathrm{mL}$ in 24-well plates with $1 \mathrm{~mL}$ of complete medium (CM) supplemented with $10 \%$ heat-inactivated human $\mathrm{AB}$ serum, $10 \mu \mathrm{M}$ HEPES buffer, $100 \mathrm{U} / \mathrm{mL}$ penicillinstreptomycin, $0.03 \%$ L-glutamine, and $10 \mathrm{mg} / \mathrm{mL}$ ciprofloxacin. Following overnight resting at $37^{\circ} \mathrm{C}$, PBMCs were stimulated with $1 \mu \mathrm{g} / \mathrm{mL}$ of pp65 and IE-1 libraries, sub-pools, or individual peptides and $0.5 \mathrm{mg} / \mathrm{mL}$ of staphylococcal enterotoxin B (SEB) (Sigma, St Louis, MO) as a positive control.

After $1 \mathrm{~h}$ of incubation at $37^{\circ} \mathrm{C}, 2 \mu \mathrm{g} / \mathrm{ml}$ of Brefeldin A (BFA) (Sigma) was added, and the cells were incubated for an additional $5 \mathrm{~h}$ before harvesting, fixed in FACS Lysing Solution (BD Biosciences, San Jose, CA) at room temperature and rested overnight at $4{ }^{\circ} \mathrm{C}$. The following day PBMCs were washed, permeabilized in Perm2 Solution 


\begin{abstract}
pp65 protein
MESRGRRCPEMASVLGPISGHVLKAVFSRGDTPVLPHETRLLQTGIHVRVSQPSLILVSQYTPDSTPCHRGDNQLQVQHTYFTGSEVENVSVNVHNPTG RS ICPSQEPMS I YVYALPLKMLNI PS INVHHY PSAAERKHRHLPVADAVI HASGKQMWQARLTVSGLAWTRQQNQWKEPDVYYTSAFVFPTKDVALRHV VCAHELVCSMENTRATKMQVIGDQYVKVYLESFCEDVPSGKLFMHVT LGS DVEEDLTMTRNPQPFMRPHERNGFTVLCPKNMI IKPGKI SH IMLDVAFT SHEHFGLLCPKS I PGLS ISGNLLMNGQQ I FLEVQA IRETVELRQY DPVAALFFFDIDLLLQRGPQYSEHPTFTSQYRIQGKLEYRHTWDRHDEGAAQGD DDVWTSGSDSDEELVTTERKTPRVTGGGAMAGASTSAGRKRKSASSATACTAGVMTRGRLKAESTVAPEEDTDEDSDNEIHNPAVFTWPPWQAGILARN LVPMVATVQGQNLKYQEFFWDANDIYRIFAELEGVWQPAAQPKRRRHRQDALPGPCIASTPKKHRG
\end{abstract}
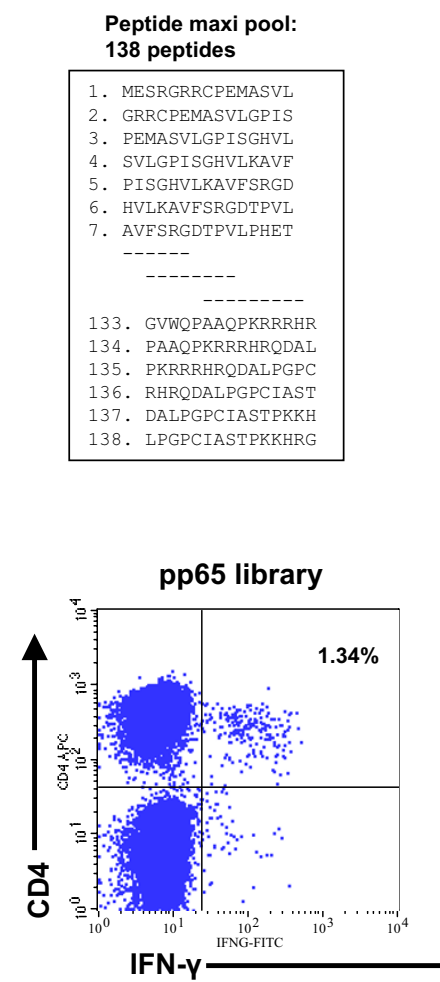
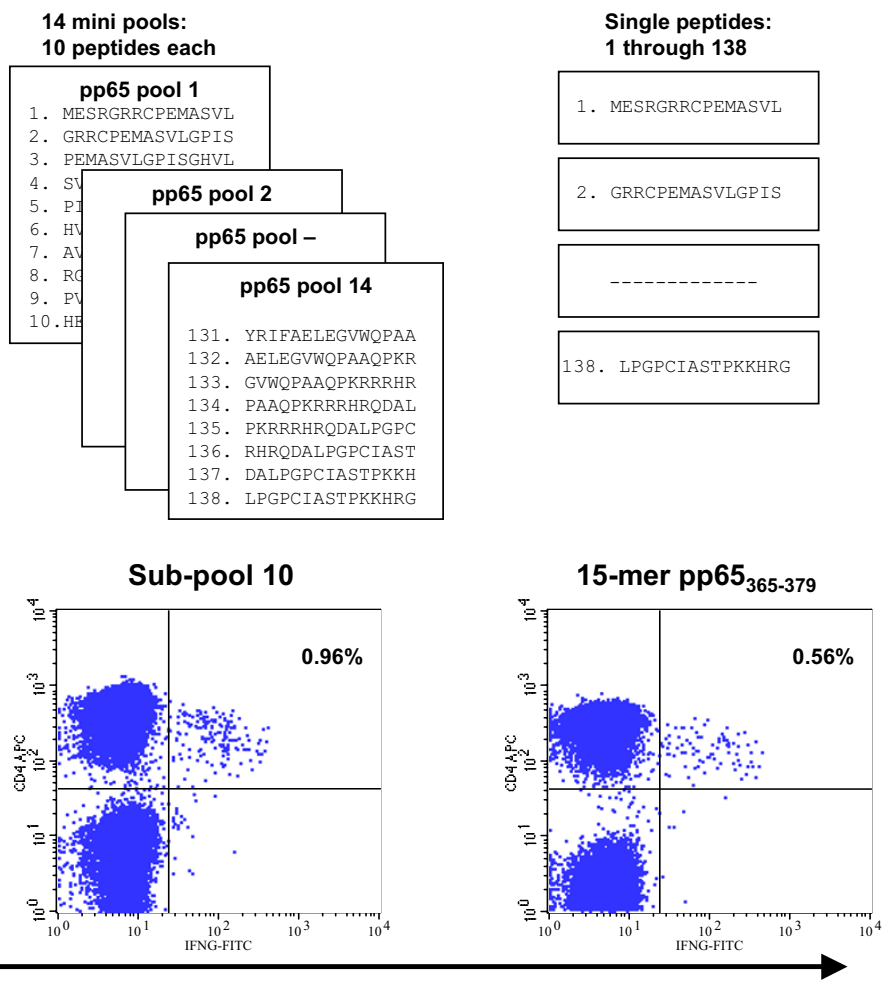

\title{
Figure I
}

Identification of CMV pp65 epitopes using 15-mer and nanomer peptides. PBMCs were stimulated with a library of I 38 I5-mer peptides overlapping by II residues and covering the entire pp65 protein. IFN- $\gamma$ flow cytometry was used to detect T cell responses. To identify specific epitopes, PBMCs were stimulated with subpools containing 10 overlapping 15 -mer peptides. PBMCs from donors reactive with CD4+ $T$ cells were tested further with individual I5-mers. The results of analysis of CD4+ T cell responses in donor 14 to pp65 peptides are shown.

and stained with monoclonal antibodies against CD3PerCP, CD8-PE, CD4-APC and IFN $\gamma$-FITC (all from BD Biosciences) and incubated at $4^{\circ} \mathrm{C}$ for 30 minutes. Mouse Ig isotype controls were also used (BD Biosciences). The 2laser FACSCalibur flow cytometer and CellQuest Pro software (BD Biosciences) were used for analysis by acquiring 200,000 events, and determining the viable lymphocyte population by light scatter. Gates were designed for CD3+ expression and for characterization of CD8+ and CD4+ subpopulations. The proportion of reactive CD8+ and $\mathrm{CD} 4+$ cells was expressed as a percent of the total number of CD8+ and CD4+ cells analyzed, respectively.

Reactive populations met 2 criteria: (1) well-defined cell population reactive with both IFN- $\gamma$ and $\mathrm{CD} 8+$ or $\mathrm{CD} 4+$, and (2) the percentage of IFN- $\gamma$ producing cells was greater than 3 standard deviations of the percentage of unstimulated IFN- $\gamma$ producing cells. Scattered reactive cells were not sufficient to be considered a positive population.

\section{Determination of HLA restriction}

Epitope HLA restrictions were determined by testing the ability of peptide-pulsed Epstein-Barr Virus (EBV) transformed lymphoblastoid B cell lines (EBV-LCL) to stimulate $\mathrm{T}$ cells that were sensitized in vitro with the same peptide. In vitro sensitization involved an 8 to 10 day cell culture in the presence of the determined CMV nanomers or 15-mers. PBMCs were plated at a concentration of $1 \times$ $10^{7}$ PBMC per $\mathrm{mL}$ in a 24 well-plate with $2 \mathrm{~mL} \mathrm{CM}$, and 
IE-1 protein

MESSAKRKMDPDNPDEGPSSKVPRPETPVTKATTFLQTMLRKEVNSQLSLGDPLFPELAEESLKTFEQVTEDCNENPEKDVLAELVKQI KVRVDMVRHR I KEHMLKKYTQTEEKFTGAFNMMGGCLQNALDI LDKVHEPFEEMKCIGLTMQSMYENYIVPEDKREMWMACI KELHDVSKGAANKLGGALQAKARAKKD ELRRKMMYMCYRNIEFFTKNSAFPKTTNGCSQAMAALQNLPQCSPDEIMAYAQKIFKILDEERDKVLTHIDHIFMDILTTCVETMCNEYKVTSDACMMT MYGGISLLSEFCRVLCCYVLEETSVMLAKRPLITKPEVISVMKRRIEEICMKVFAQYILGADPLRVCSPSVDDLRAIAEESDEEEAIVAYTLATAGVSS SDSLVSPPESPVPATIPLSSVIVAENSDQEESEQSDEEEEEGAQEEREDTVSVKSEPVSEIEEVAPEEEEDGAEEPTASGGKSTHPMVTRSKADQ
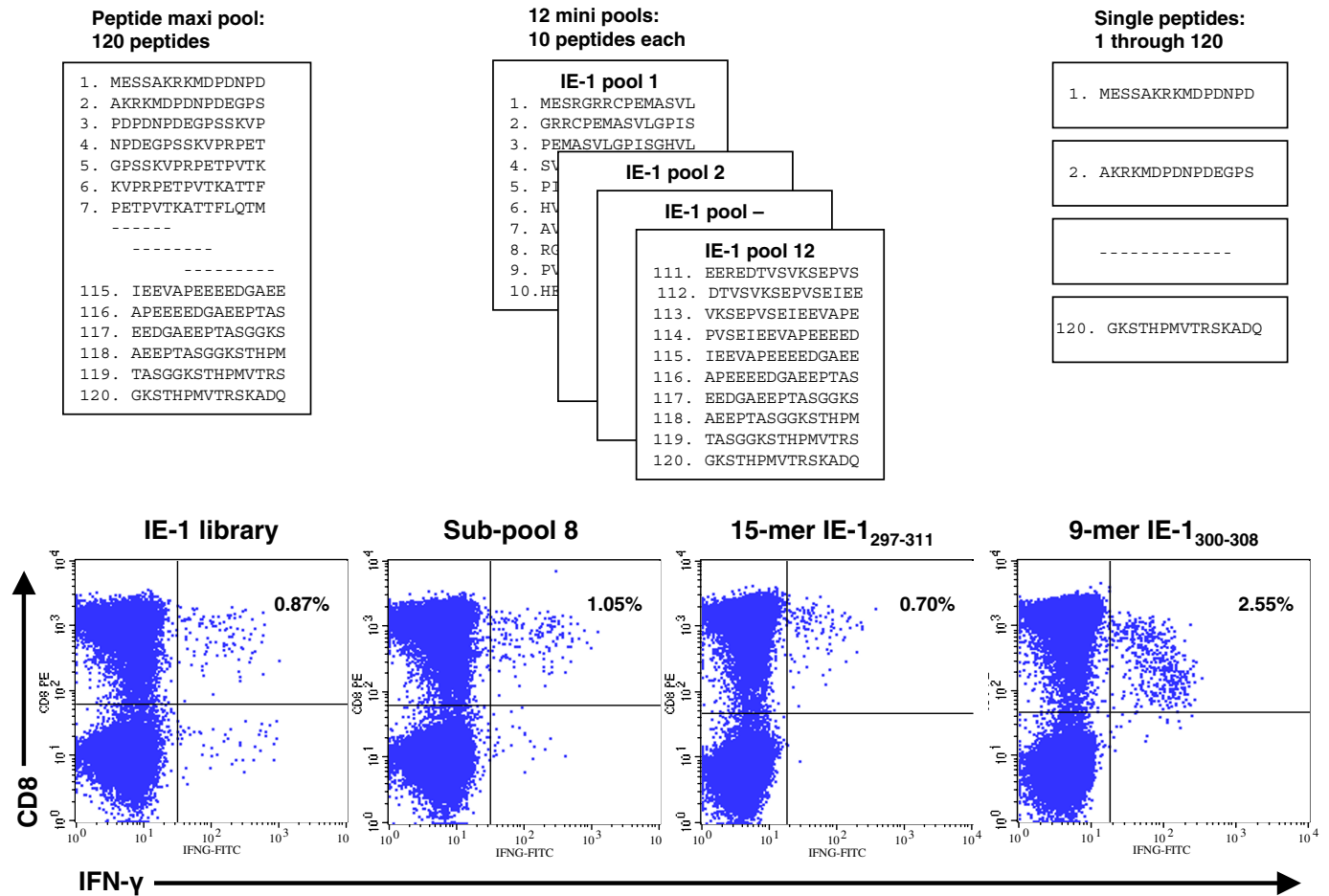

\section{Figure 2}

Identification of CMV IE-I epitopes using I 5-mer and nanomer peptides. PBMCs were stimulated with a library of I 20 I5-mer peptides overlapping by II residues and covering the entire IE-I protein. IFN- $\gamma$ flow cytometry was used to detect $T$ cell responses. To identify specific epitopes, PBMCs were stimulated with peptide subpools containing 10 overlapping $15-$ mer peptides. PBMCs from donors with reactive CD8+ T cells were tested further with individual I5-mers and nanomers. The results of analysis of CD8+ T cell responses in donor 6 to IE-I peptides are shown.

directly stimulated with $1 \mu \mathrm{g} / \mathrm{mL}$ of pre-determined peptide. Recombinant human interleukin-2 $(50 \mathrm{U} / \mathrm{mL}$, Chiron, Emeryville, CA) was added to the cells at 24 hours and every other day.

Partially HLA matched EBV-LCL panels were developed for each donor, to match HLA class I or class II antigens. EBV-LCLs in CM were pulsed with $1 \mu \mathrm{g} / \mathrm{mL}$ of peptide and incubated at $37^{\circ} \mathrm{C}$ for $1 \mathrm{~h}$, mixing vigorously at $30 \mathrm{~m}$ intervals. Washed EBV-LCLs were resuspended in CM at 1 $\times 10^{6}$ cells per $\mathrm{mL}$, and $1 \mathrm{~mL}$ was added to the sensitized cells which were plated according to the methods described above. The plates were centrifuged for $2 \mathrm{~min}$ utes at $500 \mathrm{rpm}$ and incubated for $1 \mathrm{~h}$ at $37^{\circ} \mathrm{C}$ before adding $2 \mu \mathrm{g} / \mathrm{mL}$ of BFA and incubating for an additional $5 \mathrm{~h}$. Samples were treated and analyzed as described above.

\section{Results}

Peripheral blood was obtained from 25 healthy subjects; $20 \mathrm{CMV}$-seropositive and $5 \mathrm{CMV}$-seronegative, similar in age, gender, and race (Table 1 ). The HLA types of the subjects were representative of the general population (Table 2). PBMCs from all 25 subjects were tested against the complete pp65 peptide library and subpools (Figure 1) and the complete IE-1 peptide library and subpools (Figure 2).

\section{$T$ cell responses to the complete Pp65 and IE-I peptide libraries}

Neither the complete pp65 or IE-1 libraries stimulated CD8+ or CD4+ T cells from the $5 \mathrm{CMV}$-seronegative subjects (Table 3 ). The proportion of CD8+ cells producing intracellular IFN- $\gamma$ in response to the pp65 library ranged from $0.02 \%$ to $0.09 \%$, and in response to the IE- 1 library 
Table I: Age, Gender, and Race of Subjects Studied

\begin{tabular}{lccc}
\hline & CMV-Seropositive $\mathbf{n}=\mathbf{2 0}$ & CMV-Seronegative $\mathbf{n}=\mathbf{5}$ & All $\mathbf{n}=\mathbf{2 5}$ \\
\hline Age, years & & & 44.6 \\
\hline Median & 45.1 & 42.8 & $17-64$ \\
Range & $17-64$ & $35-49$ & \\
Gender & & & 80 \\
\hline Male, \% & 80 & 80 & \\
Race & & & 56 \\
White, \% & 55 & 60 & 36 \\
Black, \% & 40 & 20 & 4 \\
Hispanic, \% & 5 & 0 & 4 \\
\hline
\end{tabular}

ranged from $0.00 \%$ to $0.05 \%$. The proportion of CD4+ cells producing IFN- $\gamma$ in response to the pp65 library ranged from $0.00 \%$ to $0.04 \%$ and in response to the IE- 1 library ranged from $0.01 \%$ to $0.04 \%$. PBMCs were also tested against the subpools, none of which induced significant IFN- $\gamma$.

Testing PBMCs from each of the $20 \mathrm{CMV}$-seropositive subjects revealed that the pp65 and IE- 1 libraries stimulated CD8+ T cells in $7(35 \%)$ and $8(40 \%)$ subjects, respectively. IFN- $\gamma$ producing cells ranged from $0.12 \%$ to $0.70 \%$ for pp65 and $0.32 \%$ to $2.06 \%$ for IE-1 (Table 4). CD4+ cells were stimulated by the pp65 library in $10(50 \%)$ subjects with the percent of IFN- $\gamma$ producing cells ranging from $0.11 \%$ to $3.33 \%$, but were not stimulated in any donors by the IE-1 library (Table 4 ).

\section{CD8+ $T$ cell responses to $\mathrm{pp} 65$ peptides}

Testing of PBMCs from all $20 \mathrm{CMV}$-seropositive donors against the pp 65 subpools revealed that all 7 subjects with CD8+ cells that were reactive to the pp65 library reacted to at least 1 pp65 subpool. We identified 5 reactive pp65 subpools, with subpool 11 stimulating CD8+ cells from 3 subjects (Table 5).

All of the 15-mer peptides in each of the reactive subpools, 3, 5, 6, 11, and 13 were tested against PBMCs from the corresponding subjects, and we identified 6 reactive pp65 15-mer peptides (Figure 3). Four of the 6 reactive peptides each elicited a CD8+ T cell response in 1 subject, donors $5,10,13$, and 19 . The other 2 reactive peptides were overlapping 15-mers that elicited responses in donors 3, 7 and 14 .

Since HLA class I antigens usually present peptides of 9 or 10 amino acids long to CD8+ T cells, nanomers were synthesized that spanned each reactive 15-mer and that overlapped by 8 amino acids. We identified 5 epitopes by testing each nanomer against PBMCs from donor(s) reactive with the corresponding 15-mer (Figure 3). Three of the 15-mers each yielded 1 epitope, pp65 $5_{123-131}$, pp65 $65_{188-}$ ${ }_{196}$, and pp6 $5_{495-503}$, in donors 19,5 , and 13 , respectively (Figure 3). The nanomers spanning 2 overlapping 15mers, pp65 $5_{413-427}$ and pp65 $417-431$, yielded 2 epitopes, pp65 $417-425$ and pp65 $418-426$ (Figure 3). However, nanomers covering pp $65_{221-235}$, did not stimulate any cells.

Both pp65 $5_{417-425}$ and pp65 $5_{418-426}$ stimulated CD8+ cells from donors 3,7 , and 14, all of whom expressed HLA$\mathrm{B}^{*} 07$ (Table 6). The restriction to HLA-B*07 was confirmed by testing donor 14 PBMCs sensitized in vitro for 10 days with pp65 ${ }_{418-426}$ against EBV-LCLs pulsed with pp65 $418-426$. CD8+ IFN- $\gamma$ production was detected when the in vitro sensitized PBMCs were tested against peptideloaded EBV-LCLs expressing HLA-B*07, but not those expressing the other donor 14 HLA class I antigens. Similar epitopes, pp $65_{415-429}$ and pp $65_{417-426}$ have been previously found to be presented by HLA-B*07[8,19].

The peptide pp $65_{123-131}$ has been described as restricted to HLA-B*35, and we found this peptide to stimulate CD8+ cells from donor 19, who also expressed HLA-B*35 (Table 6)[20]. This restriction was confirmed by testing donor 19 PBMCs that were ex vivo sensitized with pp65 $65_{123-131}$ against EBV-LCLs loaded with pp65 $5_{123-131}$ CD8+ T cells produced IFN- $\gamma$ when tested against $\mathrm{pp} 65_{123-131}$-loaded EBV-LCLs expressing HLA-B*35 but not those expressing other donor 19 HLA class I antigens.

The epitope pp65 $495-503$ stimulated CD8+ cells from donor 13, who expressed HLA-A*02 (Table 6). Since this epitope has been described by several groups as being restricted to $\mathrm{HLA}^{*} \mathrm{~A}^{*} 02$, we did not test this peptide further $[8,13,21]$. 
Table 2: HLA Genotype of the 20 CMV-Seropositive Subjects Studied

\begin{tabular}{|c|c|c|c|c|c|c|c|}
\hline \multirow{3}{*}{ Donor } & \multirow{3}{*}{ Race } & \multicolumn{6}{|c|}{ HLA Type } \\
\hline & & \multicolumn{3}{|c|}{ Class I } & \multicolumn{3}{|c|}{ Class II } \\
\hline & & $\mathbf{A}^{*}$ & B* & $\mathbf{C}^{*}$ & DRB I* & DRB- & DQB I* \\
\hline 1 & Black & 01,0301 & $|5,8|$ & 05,18 & 0901,11 & $3^{*} 00,4 * 01$ & 02,06 \\
\hline 2 & Caucasian & 24,32 & 07,40 & 02,07 & 0401,1302 & $3 * 0301,4 * 0103$ & 03,0609 \\
\hline 3 & Caucasian & 01,31 & 07,27 & 0202,0702 & 0801,1501 & $5 * 0 \mathrm{I}, 5 * 0 \mathrm{I}$ & 04,06 \\
\hline 4 & Black & 30,3601 & 53,53 & 04,04 & 03,1001 & $3 * 0 I, 3 * 0 I$ & 04,05 \\
\hline 5 & Hispanic & 11,68 & 44,45 & 05,06 & 0404,1101 & $3 * 02,4 * 0103$ & 03,03 \\
\hline 6 & Black & 26,30 & 35,57 & 04,18 & 11,16 & $3 * 02,5 * 02$ & 0301,05 \\
\hline 7 & Caucasian & 01, 0201 & 07,35 & 04,07 & 040I, 070I & $4 * 01,4 * 01$ & 0303,03 \\
\hline 8 & Black & 0202,30 & 4901,53 & 04,07 & 13031,1503 & $3 * 02,3 * 02$ & 02,06 \\
\hline 9 & Caucasian & 23,32 & $35,4 I$ & 04,17 & 11,11 & $3 * 02,3 * 02$ & 03,06 \\
\hline 10 & Black & 0301,68 & 53,58 & 04,06 & 070I, I302 & $3 * 030 \mathrm{I}, 4 * 040 \mathrm{I}$ & 0202,0604 \\
\hline 11 & Black & 26,74 & 15,5802 & 0602,1601 & 0102,1101 & $3 * 0202,3 * 0202$ & 0301,0501 \\
\hline 12 & Black & 0202,68 & 5301,5301 & 04,04 & 03021,1503 & $3 * 0$ I, $5 * 0 \mathrm{I}$ & 04,06 \\
\hline 13 & Caucasian & 0201,0201 & 15,18 & 03,07 & 13,1501 & $3 * 02,5 * 01$ & 06,06 \\
\hline 14 & Caucasian & 010101,2601 & 07020I, 380I & 07020I, I2030I & 0402,1101 & $3 * 02,4 * 0103$ & 0301,0302 \\
\hline 15 & Caucasian & 0201, 30 & 18,44 & 0501,0501 & 04,13 & $3 * 02,4 * 01$ & 03,06 \\
\hline 16 & Caucasian & 0201, II & 07,40 & 03,07 & 0301,1501 & $3 * 01,5 * 01$ & 02,06 \\
\hline 17 & Caucasian & 0201,0201 & 15,18 & 03,07 & $13,150 \mid$ & $3 * 02,5 * 01$ & 06,06 \\
\hline 18 & Black & $230 \mathrm{I}, 24$ & 07,18 & 0202,0702 & 07,15 & $4 * 0 \mathrm{I}, 5 * 0 \mathrm{I}$ & 02,06 \\
\hline 19 & Caucasian & 03,29 & 35,44 & 04,1601 & 01,0701 & $4^{*} 0 \mathrm{I}, 4^{*} 0 \mathrm{I}$ & 0202,0501 \\
\hline 20 & Caucasian & 03,11 & 07,5601 & 01,07 & 0101,0701 & $4^{*} 0 \mathrm{I}, 4^{*} 0 \mathrm{I}$ & 02,0501 \\
\hline
\end{tabular}

The epitope pp65 ${ }_{188-196}$ stimulated CD8+ cells from donor 5 , who expressed HLA-A*05; $-\mathrm{B}^{*} 11,68$, and $-\mathrm{C}^{*} 05$, 06 (Table 6). Unfortunately, no PBMCs were available to test. However, pp65 ${ }_{186-196}$ has been described as being restricted to HLA-B*35 and HLA-A*6801/02[20], so it is possible that in this donor, pp65 ${ }_{188-196}$ is restricted to HLA-A*68[8,21].

\section{CD8+ $T$ cell responses to IE-I peptides}

The 12 IE- 1 subpools were tested against all 20 subjects and 4 subpools induced IFN- $\gamma$ in 8 subjects (Table 7). At least 1 IE- 1 subpool induced IFN- $\gamma$ production in CD $8+T$ cells from all 8 subjects with cells reactive with the IE-1 library. One subpool stimulated CD8+ cells in 5 subjects, another stimulated CD8+ cells in 3 subjects, and 2 other subpools stimulated CD8+ cells from 1 subject (Table 7).
Testing the 15-mers in IE-1 subpool 5 against PBMCs from donor 15 identified IE- $1_{197-211}$ as the reactive 15 -mer and IE- $1_{198-206}$ as the reactive nanomer (Figure 4). Testing the 15-mers in subpool 10 against cells from donor 15 revealed that IE- $1_{373-387}$ as the reactive 15 -mer and IE$1_{378-386}$ as the reactive nanomer (Figure 4 ), and testing of subpool 3 peptides against PBMCs from donors 5, 10, and 11 identified IE- $1_{81-95}$ and IE- $1_{87-95}$ as the reactive 15 -mer and nanomer (Figure 4).

Testing subpool 8 peptides revealed that one 15-mer and 1 nanomer were reactive with cells from donor 6 , IE- $1_{297-}$ 311 (Figure 5a) and IE- $1_{300-308}$ (Figure 5b), respectively. Testing of subpool 8 peptides against cells from donors 2 , 5 , and 7 identified 3 reactive 15 -mers: IE- $1_{305-319}$, IE- $1_{309-}$ 323 , and IE- 1313-327 (Figure 5a), and 4 reactive nanomers:

Table 3: Proportion of Peripheral Blood CD8+ and CD4+ T Cells from 5 Healthy CMV-Seronegative Subjects Producing Intracellular IFN- $\gamma$ Following Stimulation With a Library of 138 CMV pp65 or 120 CMV IE-I I5-mer Peptides

\begin{tabular}{lllllll}
\hline \multicolumn{5}{c}{ Proportion of T Cells Producing Intracellular IFN- $\gamma(\%)$ in Each Donor } \\
\hline Library & Cell Type & $\mathbf{I}$ & $\mathbf{2}$ & $\mathbf{3}$ & $\mathbf{4}$ & $\mathbf{5}$ \\
\hline PP65 & CD8+ & 0.02 & 0.03 & 0.03 & 0.08 & 0.09 \\
IE-I & CD8+ & 0.04 & 0.02 & 0.01 & 0.00 & 0.05 \\
\hline PP65 & CD4+ & 0.00 & 0.03 & 0.02 & 0.02 & 0.03 \\
IE-I & CD4+ & 0.01 & 0.01 & 0.02 & 0.01 & 0.04 \\
\hline
\end{tabular}


Table 4: Proportion of Peripheral Blood CD8+ and CD4+ T Cells From 20 Healthy CMV-Seropositive Subjects Producing Intracellular IFN- $\gamma$ Following Stimulation With a Library of I38 CMV pp65 or I 20 CMV IE-I I5-mer Peptides

\begin{tabular}{|c|c|c|c|c|c|c|c|c|c|c|c|c|c|c|c|c|c|c|c|c|c|}
\hline \multirow[b]{2}{*}{ Library } & \multirow[b]{2}{*}{ Cell } & \multicolumn{20}{|c|}{ Proportion of T Cells Producing Intracellular IFN $-\gamma(\%)$ in Each Donor } \\
\hline & & $\mathbf{I}$ & 2 & 3 & 4 & 5 & 6 & 7 & 8 & 9 & 10 & II & 12 & 13 & 14 & 15 & 16 & 17 & 18 & 19 & 20 \\
\hline pp65 & CD8+ & 0.02 & 0.06 & 0.37 & 0.10 & 0.27 & 0.13 & 0.70 & 0.13 & 0.13 & 0.27 & 0.11 & 0.18 & 0.12 & 0.27 & 0.07 & 0.08 & 0.06 & 0.05 & 0.18 & 0.03 \\
\hline IE-I & CD8+ & 0.05 & 0.46 & 2.06 & 0.04 & 1.65 & 0.87 & 1.37 & 0.13 & 0.15 & 0.33 & 0.32 & 0.06 & 0.02 & 0.12 & $I .4 I$ & 0.05 & 0.05 & 0.02 & 0.03 & 0.08 \\
\hline pp65 & CD4+ & 0.16 & 0.06 & 0.00 & 0.06 & 0.11 & 0.76 & 0.11 & 0.65 & 0.08 & 0.21 & 3.33 & 0.18 & 0.20 & 1.34 & 0.23 & 0.02 & 0.15 & 0.03 & 0.04 & 0.01 \\
\hline IE-I & CD4+ & 0.02 & 0.04 & 0.01 & 0.03 & 0.02 & 0.14 & 0.03 & 0.05 & 0.01 & 0.02 & 0.08 & 0.06 & 0.04 & 0.13 & 0.09 & 0.02 & 0.05 & 0.02 & 0.00 & 0.10 \\
\hline
\end{tabular}

*Positive CD8+ T cell assays are indicated in bold, italics.

IE-1 305-313, $_{\text {IE- } 1_{308-316}, \text { IE-1 }}$ 312-320, and IE-1 319-327 $_{\text {(Figure }}$ 5c).

Among the 8 IE- 1 epitopes identified, IE- $1_{87-95}$, IE- $1_{300-}$ 308, IE- $1_{305-313}$, IE-1 $312-320$, and IE- $1_{319-327}$ have not been previously described. The peptide IE- $1_{87-95}$ stimulated CD8+ cells from 3 donors, all of whom expressed HLA$\mathrm{C}^{*} 06$ (Table 8 ) and this restriction was confirmed by testing donor 11 in vitro sensitized PBMCs against IE- $1_{87-95^{-}}$ loaded EBV-LCLs.

The peptide IE- $1_{305-313}$ stimulated cells from donor 7 , who expressed HLA-A*01, 0201; -B*07, 35; and -C*04, 07. Testing donor 7 PBMCs that were in vitro sensitized with IE- $1_{305-313}$ against IE-1 $1_{305-313}$-loaded EBV-LCLs confirmed that this epitope was restricted to HLA-C*07 (Table 8).

The peptide IE- $1_{308-316}$ stimulated cells from donors 2 and 7 , both expressing HLA-B*07 and $-\mathrm{C}^{*} 07$. Testing donor 7
PBMCs that were in vitro sensitized with IE- $1_{308-316}$ against IE-1 ${ }_{308-316}$-loaded EBV-LCLs confirmed the restriction to HLA-C*07 (Table 8). However, an overlapping peptide, IE- $1_{309-317}$, has been reported to be restricted to HLA-B*0702[9].

The peptide IE- $1_{312-320}$ stimulated cells from donor 7 and testing of PBMCs that were in vitro sensitized with IE$1_{312-320}$ against peptide-loaded EBV-LCLs revealed restriction to HLA-C*07 (Table 8).

The peptide IE- $1_{319-327}$ stimulated cells from donor 5, who expressed $A^{*} 11,68 ;-B^{*} 44,45$; and $-C^{*} 05,06$. Testing PBMCs that were in vitro sensitized with IE- $1_{319-327}$ against peptide-loaded EBV-LCLs revealed that IE-1 $319-327$ was restricted to HLA-A*68.

The peptide IE- $1_{300-308}$ stimulated CD8+ cells from donor 6 however, no PBMCs were available for testing.

Table 5: Proportion of Peripheral Blood CD8+ T Cells From 20 Healthy CMV-Seropositive Subjects Producing Intracellular IFN- $\gamma$ Following Stimulation With a Library of 138 CMV pp65 I5-mer Peptides and Each of 14 subpools of 10 Peptides*

CD8+ T Cells Producing Intracellular IFN- $\gamma$ in Each Donor (\%)

\begin{tabular}{|c|c|c|c|c|c|c|c|c|c|c|c|c|c|c|c|c|c|c|c|c|}
\hline & I & 2 & 3 & 4 & 5 & 6 & 7 & 8 & 9 & 10 & II & 12 & 13 & 14 & 15 & 16 & 17 & 18 & 19 & 20 \\
\hline $\begin{array}{l}\text { Library } \\
\text { Subpool }\end{array}$ & 0.02 & 0.06 & 0.37 & 0.10 & 0.27 & 0.13 & 0.70 & 0.13 & 0.13 & 0.27 & 0.11 & 0.18 & 0.12 & 0.27 & 0.07 & 0.08 & 0.06 & 0.05 & 0.18 & 0.03 \\
\hline i & 0.01 & 0.04 & 0.07 & 0.03 & 0.01 & 0.02 & 0.02 & 0.02 & 0.01 & 0.01 & 0.12 & 0.09 & 0.14 & 0.03 & 0.01 & 0.08 & 0.01 & 0.00 & 0.02 & 0.03 \\
\hline 2 & 0.01 & 0.05 & 0.02 & 0.03 & 0.17 & 0.05 & 0.11 & 0.05 & 0.06 & 0.03 & 0.03 & 0.08 & 0.01 & 0.03 & 0.06 & 0.08 & 0.03 & 0.03 & 0.03 & 0.02 \\
\hline 3 & 0.02 & 0.02 & 0.07 & 0.13 & 0.04 & 0.06 & 0.15 & 0.01 & 0.03 & 0.02 & 0.03 & 0.16 & 0.03 & 0.04 & 0.03 & 0.03 & 0.05 & 0.01 & 0.27 & 0.02 \\
\hline 4 & 0.02 & 0.04 & 0.03 & 0.01 & 0.10 & 0.08 & 0.18 & 0.08 & 0.06 & 0.09 & 0.01 & 0.08 & 0.02 & 0.05 & 0.07 & 0.02 & 0.00 & 0.05 & 0.05 & 0.02 \\
\hline 5 & 0.04 & 0.01 & 0.02 & 0.03 & 0.13 & 0.04 & 0.08 & 0.07 & 0.11 & 0.00 & 0.04 & 0.06 & 0.08 & 0.02 & 0.03 & 0.08 & 0.01 & 0.01 & 0.03 & 0.02 \\
\hline 6 & 0.00 & 0.01 & 0.00 & 0.14 & 0.08 & 0.03 & 0.04 & 0.05 & 0.08 & 0.21 & 0.05 & 0.06 & 0.03 & 0.03 & 0.11 & 0.08 & 0.03 & 0.04 & 0.01 & 0.02 \\
\hline 7 & 0.03 & 0.06 & 0.03 & 0.03 & 0.04 & 0.01 & 0.11 & 0.07 & 0.07 & 0.08 & 0.03 & 0.07 & 0.08 & 0.15 & 0.03 & 0.03 & 0.02 & 0.10 & 0.03 & 0.02 \\
\hline 8 & 0.02 & 0.00 & 0.03 & 0.01 & 0.03 & 0.10 & 0.01 & 0.10 & 0.03 & 0.01 & 0.03 & 0.08 & 0.03 & 0.02 & 0.02 & 0.10 & 0.02 & 0.04 & 0.03 & 0.05 \\
\hline 9 & 0.05 & 0.03 & 0.00 & 0.06 & 0.02 & 0.03 & 0.03 & 0.02 & 0.03 & 0.02 & 0.05 & 0.12 & 0.02 & 0.04 & 0.02 & 0.05 & 0.03 & 0.04 & 0.03 & 0.13 \\
\hline 10 & 0.06 & 0.02 & 0.00 & 0.05 & 0.02 & 0.10 & 0.14 & 0.06 & 0.03 & 0.04 & 0.06 & 0.05 & 0.02 & 0.08 & 0.03 & 0.06 & 0.03 & 0.03 & 0.04 & 0.02 \\
\hline II & 0.02 & 0.02 & 0.17 & 0.01 & 0.02 & 0.06 & 0.36 & 0.04 & 0.06 & 0.04 & 0.05 & 0.12 & 0.01 & 0.13 & 0.01 & 0.05 & 0.01 & 0.01 & 0.00 & 0.02 \\
\hline 12 & 0.12 & 0.08 & 0.03 & 0.00 & 0.07 & 0.02 & 0.06 & 0.05 & 0.09 & 0.01 & 0.03 & 0.04 & 0.01 & 0.03 & 0.00 & 0.08 & 0.02 & 0.03 & 0.02 & 0.05 \\
\hline 13 & 0.05 & 0.05 & 0.02 & 0.00 & 0.01 & 0.02 & 0.06 & 0.06 & 0.07 & 0.04 & 0.08 & 0.07 & 0.12 & 0.03 & 0.04 & 0.03 & 0.09 & 0.03 & 0.01 & 0.02 \\
\hline 14 & 0.03 & 0.01 & 0.02 & 0.01 & 0.10 & 0.04 & 0.06 & 0.07 & 0.08 & 0.08 & 0.06 & 0.07 & 0.02 & 0.01 & 0.03 & 0.02 & 0.02 & 0.05 & 0.04 & 0.00 \\
\hline
\end{tabular}

* Subpool 14 contained 8 peptides

Positive CD8+ T cell assays are indicated in bold and italics. 


\begin{tabular}{|c|c|c|c|}
\hline & pp65 Sub-pool & 15-mer & 9-mer \\
\hline Donor 19 & $\begin{array}{c}\text { Sub-pool } 3 \\
0.27 \% \text { IFN- }++\end{array}$ & $\begin{array}{c}\text { pp65 } \\
0.62 \% \text { IFN- IF- }+\end{array}$ & $\begin{array}{c}\text { pp65 }_{123-131} \\
0.26 \% \text { IFN-ү+ }\end{array}$ \\
\hline Donor 5 & $\begin{array}{c}\text { Sub-pool } 5 \\
0.13 \% \text { IFN- }++\end{array}$ & $\begin{array}{c}\text { pp65 }_{185-199} \\
0.09 \% \text { IFN- }++\end{array}$ & $\begin{array}{c}\text { pp65 }_{188-196} \\
0.06 \% \text { IFN-ү+ }\end{array}$ \\
\hline
\end{tabular}

Donor 10

Sub-pool 6
$0.21 \%$ IFN-y+

Donor 13
$0.21 \%$ IFN- $\mathrm{Y}+$

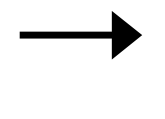

pp65

$0.25 \%$ IFN- $\gamma+$

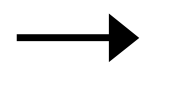

None

identified

\section{Donor 3 Donor 7}

Donor 14

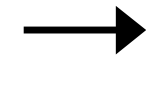

pp65 $1.05 \%$ IFN-Y+

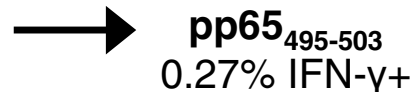

$0.27 \%$ IFN-Y+

\section{Sub-pool 11}

$0.17 \%$ IFN-y+ $0.36 \%$ IFN-y+ $0.13 \%$ IFN- $\gamma+$
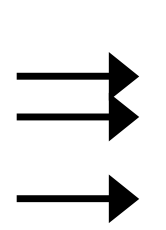

pp65

$0.35 \%$ IFN- $\mathrm{Y}+$

$0.47 \%$ IFN- $-\gamma+$

pp65

$0.25 \%$ IFN- $\gamma+$

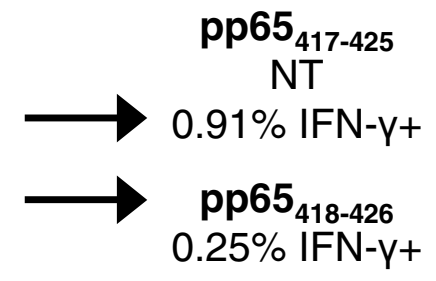

\section{Figure 3}

Identification of CMV pp65 I5-mer and nanomer epitopes recognized by CD8+ T cells. PBMCs from CMV-seropositive subjects reactive with peptides in a pp65 subpool were tested against all the individual 15-mers in each subpool. Following the identification of reactive I5-mers, nanomers overlapping at 8 amino acids and spanning the reactive 15-mer peptides were tested against PBMCs from the reactive subject. The reactive 15-mer and nanomer peptides are shown. Testing of cells from 7 subjects led to the identification of 6 pp65 I5-mers reactive with CD8+ T cells. Testing of the overlapping nanomers identified 5 epitopes. Cells from donor 3 were not available to test with the nanomer peptides. Although CD8+ T cells from donor 10 were reactive with peptides in subpool 6 and a reactive 15-mer, Pp65 $221-235$, was identified, no reactive nanomer was identified. NT = not tested.

Among the 8 IE-1 epitopes we identified, IE- $1_{199-207}$ and IE-1 $1_{379-386}$ have been previously described as restricted to HLA-B* 18 [22]. We found 2 similar epitopes reactive with donor 15 who also expressed HLA-B*18 (Table 8). Unfortunately, donor 15 PBMCs could not be expanded in vitro with either peptide, therefore we could not confirm these restrictions.

\section{CD4+ $T$ cell responses to $\mathrm{pp} 65$ peptides}

After testing pp65 peptide subpools against PBMCs from all 20 seropositive subjects, 5 subpools stimulated CD4+ cells in each of the 10 subjects who were responsive to the pp65 library (Table 9). Subpool 8 stimulated CD4+ cells from 1 subject, subpool 6 from 3 subjects, subpool 10 from 4 subjects, and subpool 13 from 5 subjects (Table 9).

All 15-mers in each reactive subpool were tested against PBMCs from the 10 subjects, revealing a total of 6 reactive pp65 15-mer epitopes. The peptide pp65 $221-235$ was identified as the reactive 15 -mer in subpool 6, pp65 $65_{285-299}$ in subpool 8, and pp65 $365-379$ in subpool 10 (Figure 6). Subpool 13 yielded 3 reactive 15-mers; pp65 $489-503^{\prime}$ pp65 $65_{505-}$ 519, and pp65 $509-523$ (Figure 7).

Epitope pp65 $221-235$ reacted with PBMCs from donors 8, 10 , and 12 (Table 10). Donor 12 PBMCs were in vitro sen- 
Table 6: Individual pp65 Epitopes that Induced Intracellular IFN- $\gamma$ Production by CD8+ T Cells, the HLA Type of Donors With Reactive CD8+ T Cells, and HLA Antigen Restrictions of Each Epitope

\begin{tabular}{|c|c|c|c|c|c|c|}
\hline Epitope(s) & Donor & HLA-A* & HLA-B* & HLA-C* & HLA Antigen Restriction & Published Antigen Restriction \\
\hline pp65 $123-131$ & 19 & 03,29 & 35,44 & 04,1601 & $\mathrm{~B} * 35$ & Pp65 ${ }_{|23-13|} B * 350 \mid[20]$ \\
\hline Pp65 & 05 & 11,68 & 44,45 & 05,06 & No cells available & $\mathrm{Pp} 5_{186-196} \mathrm{~A}^{* 6801 / 2}[21]$ \\
\hline \multirow[t]{3}{*}{ PP65 $65_{417-425}$ and PP65 $418-426$} & 03 & 01,31 & 07,27 & 0202,0702 & No cells available & \\
\hline & 07 & 01,0201 & 07,35 & 04,07 & No cells available & $\mathrm{Pp} 65_{417-426} \mathrm{~B}^{* 0702}[8,19]$ \\
\hline & 14 & 010101,2601 & 070201,3801 & 070201,120301 & HLA-B*07 & \\
\hline Pp65 495-503 & 13 & 0201,0201 & 15,18 & 03,07 & Not tested & $\mathrm{Pp} 65_{495-503} \mathrm{~A}^{* 020 \mathrm{I}[13,30]}$ \\
\hline
\end{tabular}

The HLA antigen restrictions identified are shown in bold.

sitized with pp65 $221-235$, and reacted with pp65 $221-235^{\prime}-$ loaded EBV-LCLs expressing DRB $1 * 15$ and DRB5*01. It is likely that pp $65_{221-235}$ is presented by DRB $1 * 15$ since 2 of the 3 donors expressed DRB1*15 but only donor 12 expressed DRB5*01. In addition, pp65 $225-239$ has previously been reported to be restricted to DRB1*15[23].

Pp65 $65_{365-379}$ stimulated cells from 4 donors all expressing HLA-DRB1*11 (Table 10). PBMCs from donor 11 were in vitro sensitized with pp65 $365-379$, and produced IFN- $\gamma$ when tested against pp65 $65_{365-379}$-loaded EBV-LCLs expressing HLA-DRB1*11, but not when tested against those expressing HLA-DRB1*0102, DRB3*0202, DQB1*0301, and DQB1*0501. The testing of this peptide against a second subject, donor 6 , revealed similar results. Two similar epitopes, pp65 $361-376$ and pp65 $65_{361-}$ 375 , have been described as restricted to HLADR11[11,24].

Epitope pp65 $5_{489-503}$ reacted with 3 donors, all of whom expressed HLA-DRB3*02 (Table 10). Donor 6 PBMCs that were in vitro sensitized with pp $65_{489-503}$, produced IFN- $\gamma$ when tested against EBV-LCLs expressing HLA-
DRB3*02, but not when tested against the other donor 6 class II antigens. Although we found that pp $65_{489-503}$ was restricted to $\mathrm{DRB} 3 * 02$, others have described this peptide as restricted to DRB1*11 and DRB1*03 [24].

Epitope pp65 $65_{505-519}$ was reactive with PBMCs from donors 6 and 17 and testing of donor 6 pp65 $65_{505-519}$ ex vivo sensitized PBMCs against pp65 $5_{505-519}$-loaded EBVLCLs revealed presentation by DQB $1 * 0502$. Donor $17 \mathrm{did}$ not express DQB1*0502, but cells were not available for additional testing. The epitope pp $65_{505-523}$ has been reported to be restricted to DRB1*01[23] and DR52[11].

Epitope pp65 $5_{509-523}$ reacted with PBMCs from donors 12 and 14, and testing donor 12 in vitro sensitized PBMCs against loaded EBV-LCLs revealed presentation by DRB3*0101. Donor 14 did not express DRB3*0101 however, an adequate number of cells were not available for in vitro sensitization and testing. The epitope pp65 $509-524$ was previously reported to be restricted to DRB1*03[24].

Pp65 285-299 reacted with cells from donor 7, who expressed both HLA-DRB1*0401 and HLA-DRB1*0701

Table 7: Proportion of Peripheral Blood CD8+ T Cells From 20 Healthy CMV-Seropositive Subjects Producing Intracellular IFN- $\gamma$ Following Stimulation With a Library of I20 CMV IE-I I5-mer Peptides and Each of 12 Subpools of 10 Peptides

CD8+ T Cells Producing Intracellular IFN- $\gamma$ in Each Donor (\%)

\begin{tabular}{|c|c|c|c|c|c|c|c|c|c|c|c|c|c|c|c|c|c|c|c|c|}
\hline & I & 2 & 3 & 4 & 5 & 6 & 7 & 8 & 9 & 10 & II & 12 & 13 & 14 & 15 & 16 & 17 & 18 & 19 & 20 \\
\hline $\begin{array}{l}\text { Library } \\
\text { Subpool }\end{array}$ & 0.05 & 0.46 & 2.06 & 0.04 & 1.65 & 0.87 & 1.37 & 0.13 & 0.15 & 0.33 & 0.32 & 0.06 & 0.02 & 0.12 & $1.4 I$ & 0.05 & 0.05 & 0.02 & 0.03 & 0.08 \\
\hline I & 0.04 & 0.03 & 0.08 & 0.05 & 0.01 & 0.03 & 0.01 & 0.11 & 0.04 & 0.05 & 0.04 & 0.05 & 0.04 & 0.05 & 0.03 & 0.05 & 0.02 & 0.02 & 0.01 & 0.00 \\
\hline 2 & 0.05 & 0.07 & 0.06 & 0.01 & 0.07 & 0.04 & 0.06 & 0.05 & 0.10 & 0.03 & 0.02 & 0.04 & 0.02 & 0.02 & 0.01 & 0.05 & 0.01 & 0.01 & 0.01 & 0.01 \\
\hline 3 & 0.06 & 0.05 & 0.04 & 0.04 & 0.95 & 0.03 & 0.02 & 0.08 & 0.02 & 0.26 & 0.29 & 0.10 & 0.01 & 0.05 & 0.02 & 0.08 & 0.01 & 0.01 & 0.01 & 0.02 \\
\hline 4 & 0.06 & 0.07 & 0.16 & 0.05 & 0.01 & 0.05 & 0.00 & 0.00 & 0.07 & 0.04 & 0.04 & 0.06 & 0.03 & 0.03 & 0.02 & 0.08 & 0.04 & 0.03 & 0.00 & 0.02 \\
\hline 5 & 0.03 & 0.04 & 0.05 & 0.00 & 0.05 & 0.04 & 0.05 & 0.07 & 0.17 & 0.03 & 0.07 & 0.03 & 1.28 & 0.04 & 1.60 & 0.08 & 0.03 & 0.06 & 0.01 & 0.02 \\
\hline 6 & 0.02 & 0.02 & 0.17 & 0.03 & 0.05 & 0.10 & 0.01 & 0.06 & 0.06 & 0.06 & 0.06 & 0.06 & 0.03 & 0.12 & 0.05 & 0.11 & 0.02 & 0.01 & 0.04 & 0.00 \\
\hline 7 & 0.04 & 0.01 & 0.02 & 0.03 & 0.01 & 0.03 & 0.03 & 0.09 & 0.01 & 0.04 & 0.05 & 0.07 & 0.06 & 0.03 & 0.07 & 0.05 & 0.01 & 0.02 & 0.02 & 0.00 \\
\hline 8 & 0.06 & 0.43 & 1.65 & 0.00 & 0.33 & 1.05 & 1.39 & 0.07 & 0.02 & 0.01 & 0.05 & 0.04 & 0.03 & 0.12 & 0.06 & 0.00 & 0.03 & 0.01 & 0.06 & 0.00 \\
\hline 9 & 0.04 & 0.02 & 0.03 & 0.08 & 0.02 & 0.05 & 0.02 & 0.14 & 0.03 & 0.04 & 0.09 & 0.08 & 0.03 & 0.04 & 0.11 & 0.02 & 0.02 & 0.04 & 0.04 & 0.00 \\
\hline 10 & 0.04 & 0.07 & 0.08 & 0.03 & 0.03 & 0.05 & 0.00 & 0.07 & 0.08 & 0.05 & 0.05 & 0.07 & 0.04 & 0.05 & 0.25 & 0.05 & 0.01 & 0.04 & 0.04 & 0.00 \\
\hline II & 0.01 & 0.01 & 0.09 & 0.03 & 0.05 & 0.06 & 0.05 & 0.09 & 0.04 & 0.02 & 0.08 & 0.07 & 0.02 & 0.01 & 0.05 & 0.07 & 0.03 & 0.01 & 0.01 & 0.02 \\
\hline 12 & 0.02 & 0.05 & 0.11 & 0.06 & 0.07 & 0.03 & 0.02 & 0.06 & 0.03 & 0.03 & 0.05 & 0.08 & 0.06 & 0.04 & 0.04 & 0.10 & 0.02 & 0.04 & 0.03 & 0.02 \\
\hline
\end{tabular}

Positive assays are indicated in bold and italics. 


\section{IE-1 Sub-pool \\ 15-mer \\ 9-mer \\ Sub-pool 5 \\ IE-1 ${ }_{197-211}$ \\ IE-1 ${ }_{198-206}$ \\ $1.60 \% \mathrm{IFN}-\gamma^{+} \longrightarrow 1.66 \% \mathrm{IFN}-\gamma^{+} \longrightarrow 4.58 \% \mathrm{IFN}-\gamma^{+}$ \\ Donor 15

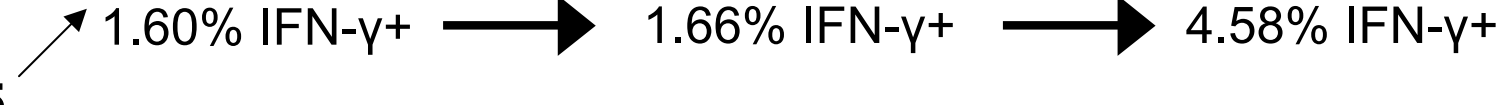
Sub-pool 10

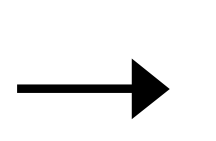
IE-1 $1_{373-387}$
IE-1 ${ }_{378-386}$
$0.36 \%$ IFN- $\gamma^{+}$ \\ $0.25 \%$ IFN- $\gamma^{+}$

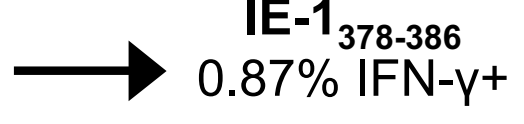 \\ Sub-pool 3 \\ IE-1 $81-95$
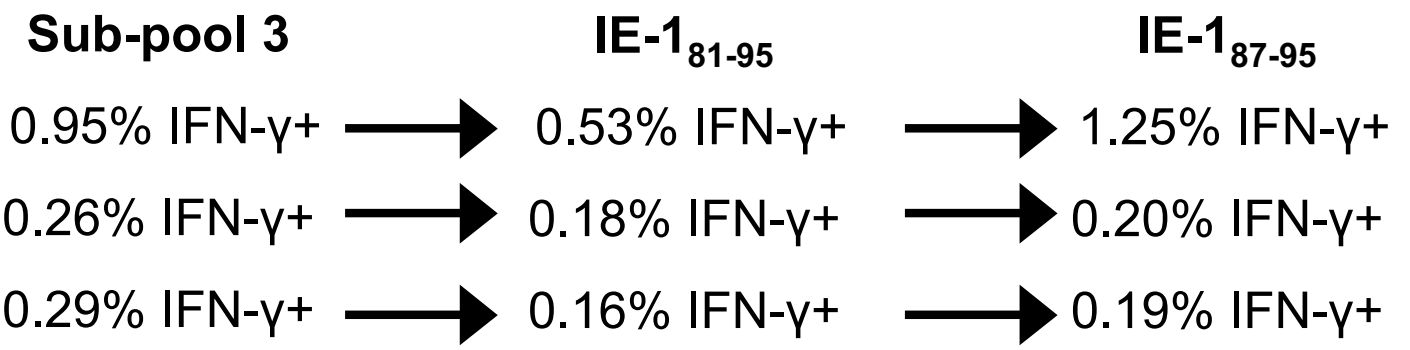 \\ Donor 5 \\ Donor 10 \\ Donor 11 \\ $0.18 \%$ IFN- $\gamma^{+}$ \\ $0.16 \%$ IFN- $\gamma^{+}$}

\section{Figure 4}

Identification of CMV IE-I I5-mer and nanomer epitopes from 3 peptide subpools reactive with CD8+ T cells. PBMCs from 4 donors were reactive with peptides in IE-I subpools 3, 5, and I0. Testing of all I5-mers in each subpool identified 3 nanomers reactive with CD8+ T cells, one from each subpool. Testing of the 6 overlapping nanomers spanning each reactive 15-mer lead to the identification of 3 nanomer epitopes.

(Table 10). Although additional PBMCs were not available for testing, a similar epitope, pp65 $281-295$, was previously found to be restricted to both HLA-DR* 4 and HLA$\mathrm{DR}^{*} 7[11]$.

\section{CD4+ $T$ cell responses to IE-I}

Testing with both the IE- 1 library and the 12 subpools did not reveal active CD4+ populations from any subjects (Table 11).

\section{Discussion}

The aim of this investigation was to map CMV pp65 and IE-1 epitopes in $20 \mathrm{CMV}$-seropositive healthy subjects in order to identify peptides that may be important in vaccination, adoptive immunotherapy, and the monitoring of transplant recipients. Among the 20 subjects, CD8+ T cell responses to pp65 and IE- 1 were detected in a similar proportion of patients: $35 \%$ versus $40 \%$. However, CD $4+\mathrm{T}$ cell responses to pp65 were more common than responses to IE-1, as $50 \%$ of subjects reacted to pp 65 but none reacted to IE-1. Using similar methodology, Kern et al also found CD8+ T cell responses in healthy subjects to both pp65 and IE-1[9,11]. While they did not specifically screen for IE-1 epitopes that were presented by CD4+ T cells, a comparison of CD4+ T cell responses to pp65 peptides with responses to CMV lysate suggested that pp65 was a dominant target of the CMV-specific CD4+ T cell response[11]. A recent analysis of overlapping 15-mers spanning $213 \mathrm{CMV}$ open reading frames including pp65 and IE-1, by Sylwester et al found that the CD8+ and $\mathrm{CD} 4+\mathrm{T}$ cell responses were directed to peptides in a variety of proteins, [25]. In addition, they found that CD8+ T cell responses to both pp65 and IE- 1 were strong and the CD4+ T cell responses were strong to pp65 but weak to IE1 which supports the results of our study [25].

We identified 4 pp65 and 8 IE- 1 nanomers presented by HLA class I, and 6 pp65 15-mers presented by HLA class II. While all 4 of the pp $65 \mathrm{CMV}$ class I epitopes have been previously described, 6 of the 8 IE- 1 class I epitopes, and 2 of the 6 pp65 class II epitopes have not. The pp65 epitopes and restrictions that we identified were similar or identical to those reported previously, but the IE-1 class I epitopes had either not been described or we identified HLA restrictions that differed from those reported.

Four of the 6 new IE-1 class I epitopes we identified were restricted to HLA-C antigens, a finding that may be corre- 
A
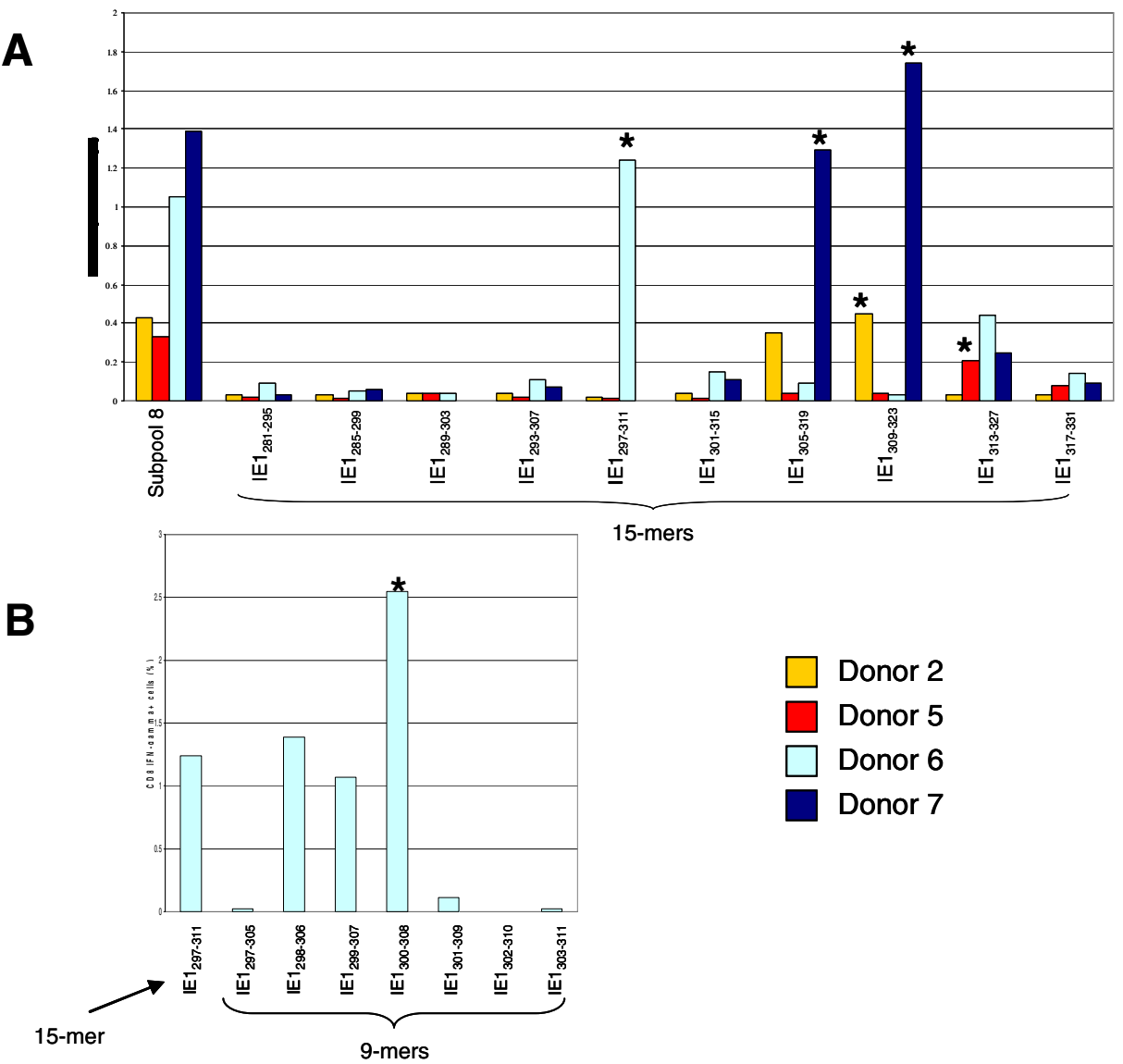

15-mers

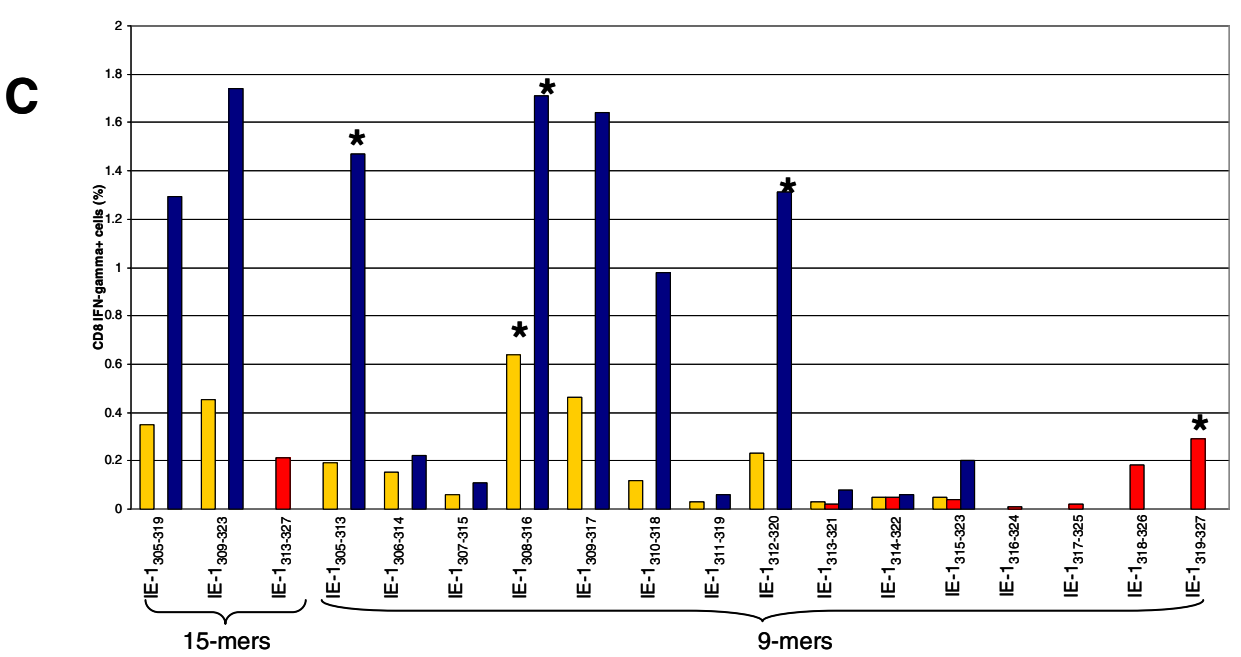

Figure 5

Identification of CMV pp65 I5-mer and nanomer epitopes from peptide subpool 8 that were reactive with CD8+ T cells. Testing of IE-I I 5-mers from subpool 8 against cells from donor 2 (gold bar), donor 5 (red bar), donor 6 (light blue bar), and donor 7 (navy blue bar) revealed that the peptide IE- $I_{297-31 I}$ was reactive with donor 6 , IE- $I_{305-319}$ was reactive with donor 7, IE-I $I_{309-323}$ was reactive with donors 2 and 6, and IE- $I_{3 \mid 3-327}$ was reactive with donor 5 (Panel A). Testing of the 6 nanomers overlapping IE- $I_{297-3 I I}$ against cells from donor 6 revealed that IE- $I_{300-308}$ was the dominant nanomer (Panel B). Testing of the nanomers spanning the overlapping I 5-mers IE- $I_{305-319}$, IE- $I_{309-323}$, and IE- $I_{313-327}$ against PBMCs from donors 2 , 5, and 7 identified 4 nanomers that were reactive with CD8+ T cells: IE- $I_{305-313}, I_{2}-I_{308-316}, I E-I_{3 \mid 2-320}$ and IE-I $I_{3 \mid 9-327},(P a n e l$ C). 
Table 8: Individual IE-I Epitopes that Induced Intracellular IFN- $\gamma$ Production by CD8+ T Cells, the HLA Type of Donors With Reactive CD8+ T Cells, and The HLA Antigen Restriction of Each Epitope.

\begin{tabular}{|c|c|c|c|c|c|c|}
\hline Epitope & Donor & HLA-A* & HLA-B* & HLA-C* & HLA Antigen Restriction & Published Antigen Restriction \\
\hline \multirow[t]{3}{*}{$\mid E-I_{87-95}$} & 05 & 11,68 & 44,45 & 05,06 & & \\
\hline & 10 & 0301,68 & 53,58 & 04,06 & & \\
\hline & 11 & 26,74 & 15,5802 & 0602,1601 & $C * 0602$ & \\
\hline IE-I $198-206$ & 15 & 0201,30 & 18,44 & 0501 & $\dagger$ & $\left|\mathrm{E}-\mathrm{I}_{\mid 99-207} \mathrm{~B} *\right| 8[22]$ \\
\hline $\mid E-I_{300-308}$ & 06 & 26,30 & 35,57 & 04,18 & No cells available & $\mathrm{IE}-\mathrm{I}_{297-304} \mathrm{~A}^{* 020 \mathrm{I}}[27]$ \\
\hline $\mid E-I_{305-313}$ & 07 & 01,0201 & 07,35 & 04,07 & $C * 0702$ & \\
\hline \multirow[t]{2}{*}{$\mathrm{IE}-\mathrm{I}_{308-316}$} & 02 & 24,32 & 07,40 & 02,07 & $C * 07$ & $\mathrm{IE}-\mathrm{I}_{309-317} \mathrm{~B} * 0702[9]$ \\
\hline & 07 & 01,0201 & 07,35 & 04,07 & & \\
\hline $\mid E-I_{3 \mid 2-320}$ & 07 & 01,0201 & 07,35 & 04,07 & $C * 07$ & \\
\hline $\mid E-I_{3 \mid 9-327}$ & 05 & 11,68 & 44,45 & 05,06 & $A * 68$ & $\mid E-I_{316-324} A^{* 020 I}[19]$ \\
\hline IE-I $378-386$ & 15 & 0201,30 & 18,44 & 0501,0501 & $\dagger$ & $\mathrm{IE}-\mathrm{I}_{379-387} \mathrm{~B} * 18[22]$ \\
\hline
\end{tabular}

† Cells from donor 15 did not expand when stimulated with IE-I ${ }_{198-206}$ and IE-I $378-386$.

The HLA antigen restrictions identified are shown in bold.

lated to the fact that all of our subjects and EBV-LCLs were HLA typed at high-resolution. Because HLA-C antigen typing results were ambiguous prior to the advent of molecular genotyping, the availability of precise molecular typing for this study may have permitted the identification of epitopes not possible in the past when molecular methods were not available or were less precise.

While the conventional thought has been that unique peptides are each presented by a specific HLA allele, some CMV epitopes are presented by multiple alleles. Epitopes for HLA class I antigens are generally believed to be very restrictive, with epitopes binding to specific HLA-types. Our results suggest that this is not entirely true for IE-1 class I epitopes as the HLA restrictions were somewhat promiscuous. We found that the epitope IE- $1_{319-327}$ was restricted to HLA-A* 68 , while a similar epitope IE-1 1316-324 $_{3}$ has been described as restricted to $A^{*} 0201$. We also found that IE- $1_{308-316}$ was restricted to HLA-C*07, but IE- $1_{309-}$ 317 is reported to be restricted to HLA-B*0702 [19]. In previous studies, we found that the epitopes pp $65_{341-349}$ and

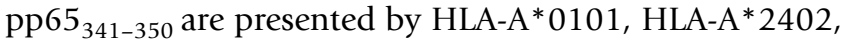
and HLA-Cw*0402 $[14,26]$.

We found that 1 region of IE- 1 , amino acid residues 300 to 327 , to be more immunogenic than other regions. We identified 5 epitopes in this region, in addition to the 3 other epitopes previously identified[9,19,27]. This region was particularly immunogenic for HLA-C*07 as we identified 3 HLA-C* 07 restricted epitopes in this region.

Table 9: Proportion of Peripheral Blood CD4+ T Cells From 20 Healthy CMV-Seropositive Subjects Producing Intracellular IFN- $\gamma$ Following Stimulation With a Library of 138 CMV pp65 I5-mer Peptides and Each of 14 subpools of 10 Peptides*

CD4+ T Cells Producing Intracellular IFN- $\gamma$ in Each Donor (\%)

\begin{tabular}{|c|c|c|c|c|c|c|c|c|c|c|c|c|c|c|c|c|c|c|c|c|}
\hline & I & 2 & 3 & 4 & 5 & 6 & 7 & 8 & 9 & 10 & II & 12 & 13 & 14 & 15 & 16 & 17 & 18 & 19 & 20 \\
\hline $\begin{array}{l}\text { Library } \\
\text { Subpool }\end{array}$ & 0.16 & 0.06 & 0.00 & 0.06 & 0.11 & 0.76 & 0.11 & 0.65 & 0.08 & 0.21 & 3.33 & 0.18 & 0.20 & 1.34 & 0.23 & 0.02 & 0.15 & 0.03 & 0.04 & 0.01 \\
\hline i & 0.01 & 0.01 & 0.02 & 0.01 & 0.02 & 0.03 & 0.00 & 0.03 & 0.02 & 0.01 & 0.03 & 0.05 & 0.08 & 0.05 & 0.04 & 0.00 & 0.02 & 0.01 & 0.01 & 0.04 \\
\hline 2 & 0.05 & 0.09 & 0.01 & 0.03 & 0.05 & 0.05 & 0.02 & 0.04 & 0.02 & 0.01 & 0.03 & 0.06 & 0.02 & 0.06 & 0.03 & 0.02 & 0.03 & 0.04 & 0.01 & 0.03 \\
\hline 3 & 0.03 & 0.02 & 0.01 & 0.01 & 0.03 & 0.03 & 0.04 & 0.05 & 0.05 & 0.03 & 0.03 & 0.06 & 0.03 & 0.06 & 0.06 & 0.00 & 0.03 & 0.02 & 0.04 & 0.02 \\
\hline 4 & 0.01 & 0.06 & 0.02 & 0.01 & 0.03 & 0.06 & 0.00 & 0.09 & 0.01 & 0.02 & 0.04 & 0.04 & 0.01 & 0.03 & 0.04 & 0.01 & 0.01 & 0.02 & 0.02 & 0.00 \\
\hline 5 & 0.02 & 0.04 & 0.01 & 0.01 & 0.02 & 0.02 & 0.00 & 0.04 & 0.04 & 0.01 & 0.04 & 0.05 & 0.02 & 0.07 & 0.02 & 0.02 & 0.01 & 0.00 & 0.01 & 0.01 \\
\hline 6 & 0.02 & 0.04 & 0.01 & 0.04 & 0.01 & 0.03 & 0.01 & 0.45 & 0.04 & 0.11 & 0.02 & 0.18 & 0.02 & 0.01 & 0.02 & 0.02 & 0.01 & 0.04 & 0.01 & 0.03 \\
\hline 7 & 0.01 & 0.05 & 0.04 & 0.01 & 0.01 & 0.02 & 0.02 & 0.03 & 0.01 & 0.07 & 0.02 & 0.06 & 0.05 & 0.04 & 0.07 & 0.02 & 0.02 & 0.07 & 0.02 & 0.01 \\
\hline 8 & 0.04 & 0.04 & 0.01 & 0.03 & 0.02 & 0.09 & 0.05 & 0.12 & 0.01 & 0.01 & 0.04 & 0.08 & 0.00 & 0.07 & 0.05 & 0.02 & 0.01 & 0.03 & 0.01 & 0.03 \\
\hline 9 & 0.06 & 0.13 & 0.03 & 0.03 & 0.03 & 0.05 & 0.05 & 0.04 & 0.03 & 0.01 & 0.05 & 0.05 & 0.01 & 0.06 & 0.02 & 0.02 & 0.01 & 0.03 & 0.02 & 0.09 \\
\hline 10 & 0.14 & 0.02 & 0.00 & 0.03 & 0.05 & 0.56 & 0.00 & 0.10 & 0.05 & 0.04 & 2.76 & 0.08 & 0.01 & 0.96 & 0.03 & 0.02 & 0.02 & 0.01 & 0.02 & 0.00 \\
\hline II & 0.03 & 0.02 & 0.00 & 0.00 & 0.02 & 0.15 & 0.00 & 0.08 & 0.01 & 0.01 & 0.06 & 0.13 & 0.01 & 0.07 & 0.01 & 0.01 & 0.01 & 0.01 & 0.00 & 0.01 \\
\hline 12 & 0.04 & 0.03 & 0.01 & 0.00 & 0.02 & 0.04 & 0.01 & 0.05 & 0.04 & 0.01 & 0.01 & 0.04 & 0.00 & 0.06 & 0.03 & 0.02 & 0.02 & 0.01 & 0.01 & 0.05 \\
\hline 13 & 0.02 & 0.03 & 0.02 & 0.03 & 0.03 & 0.27 & 0.00 & 0.13 & 0.07 & 0.07 & 0.05 & 0.12 & 0.14 & 0.42 & 0.13 & 0.01 & 0.12 & 0.02 & 0.01 & 0.00 \\
\hline 14 & 0.03 & 0.06 & 0.02 & 0.01 & 0.02 & 0.09 & 0.00 & 0.11 & 0.07 & 0.01 & 0.03 & 0.08 & 0.01 & 0.09 & 0.02 & 0.01 & 0.01 & 0.01 & 0.02 & 0.00 \\
\hline
\end{tabular}

* Subpool 14 contained 8 peptides

Positive assays are indicated in bold and italics. 
pp65 Sub-pool

Sub-pool 6 15-mer

pp65 $221-235$
Donor 8

Donor 10

Donor 12

Donor 1

Donor 6

Donor 11

Donor 14
$0.45 \%$ IFN $-\gamma^{+} \longrightarrow 1.05 \%$ IFN- $-\gamma^{+}$

$0.11 \%$ IFN- $\gamma^{+} \longrightarrow 0.17 \%$ IFN- $\gamma^{+}$

$0.18 \% \mathrm{IFN}-\gamma^{+} \longrightarrow 0.07 \% \mathrm{IFN}-\mathrm{\gamma}^{+}$

Sub-pool $8 \quad$ pp65 $285-299$

$0.05 \% \mathrm{IFN}-\gamma^{+} \longrightarrow 0.10 \% \mathrm{IFN}-\gamma^{+}$

Sub-pool $10 \quad$ pp65 $365-379$

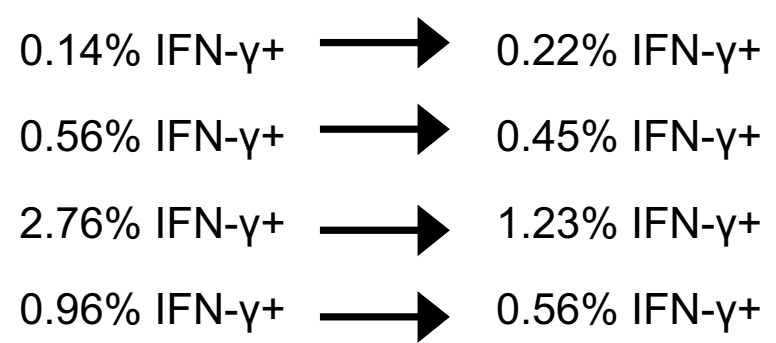

Figure 6

Identification of CMV pp65 I5-mer epitopes from 3 peptide subpools that were reactive with CD4+ T cells. PBMCs from 8 donors were reactive with peptides in subpools 6, 8, and 10. Testing of all I5-mers in each subpool identified three I5-mers that were reactive with CD4+ T cells, one from each subpool.

Although pp65 $495-503$ has been found to presented by HLA-A*02[8,13], the 15-mer in our pp65 library that encompassed this epitope, pp65 ${ }_{489-503}$, stimulated CD8+ T cells from only 1 of 6 HLA-A* 02 CMV seropositive subjects tested. To determine if the lack of response to pp65 $489-503$ was because the cells were not responsive to pp65 $5_{495-503}$ or because the epitope was not presented in the context of the 15-mer, we tested the 9-mer, pp65 495 503, against PBMCs for all 5 HLA-A*02 subjects who had not responded to pp65 $489-503$. Similarly, CD8+ cells from none of these subjects produced significant quantities of intracellular IFN- $\gamma$ in response to pp65 $695-503$ stimulation. Our study differed from most other studies in that we screened the peptide libraries against cells that had not been sensitized in vitro, while the studies that first identified pp65 $495-503$ as an immune dominant HLA-A*02 restricted epitope used $\mathrm{T}$ cells that had been stimulated with CMV-infected fibroblasts[8,13]. These results suggest that the baseline frequency of CTLs in HLA-A*0201 healthy subjects that are restricted to pp65 $65_{495-503}$ is usually low, but expand robustly when challenged with CMV antigens.

To provide optimum protection from CMV infection and disease, vaccines that elicit both CD8+ and CD4+ responses are required $[5,23]$. Cytotoxic T cells (CTL) prevent $\mathrm{CMV}$ infection from developing into $\mathrm{CMV}$ disease, and CD4+ T cell responses maintain CTLs[5]. Several vaccines to $\mathrm{CMV}$ have been tested and found to have some efficacy, including live attenuated vaccines, subunit vaccines, and peptide vaccines[28]. Subunit vaccines have focused on gB glycoprotein because it is the primary target of natural antibodies, and pp 65 because it is the major target of CTLs. Additionally, pox virus-vectored vaccines 


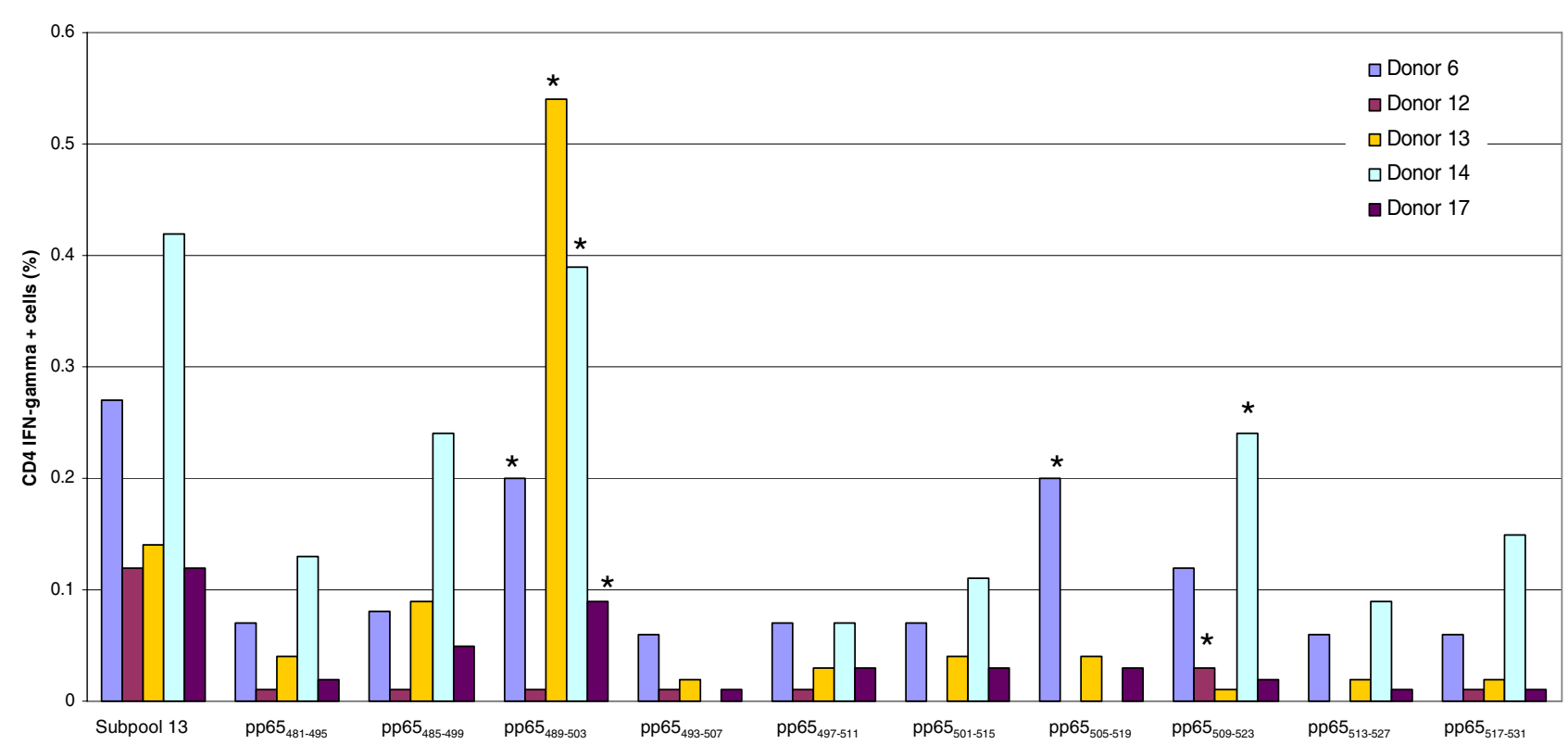

Figure 7

Identification of CMV pp65 I5-mer epitopes from peptide subpool I 3 that were reactive with CD4+ T cells. PBMCs from 5 donors were reactive with Pp65 peptides in subpool 13. Testing of all I5-mers in subpool I3 identified three I5-mers that were reactive with CD4+ T cells, Pp65 $5_{489-503}$, Pp65 $505-519$, and Pp65 $5_{509-523}$.

expressing pp65 have stimulated CD8+ T cell responses in CMV-seronegative subjects. Our finding of naturally occurring CD8+ and CD4+ T cell responses to pp65 in healthy subjects also supports its use in subunit vaccines. The naturally occurring CD8+ T cell responses to IE- 1 that we found in a large proportion of healthy subjects supports IE- 1 addition to vaccines. In fact, a trivalent DNA vaccine containing $\mathrm{gB}$, pp65, and IE-1 is being tested in phase I clinical trials[28].

In one study of lung and heart transplant recipients have revealed that protection from CMV disease is more closely associated with the CD8+ T cell responses to IE- 1 than to pp65, indicating that IE-1 is a good candidate for CMV

Table 10: Individual pp65 Epitopes that Induced intracellular IFN- $\gamma$ Production by CD4+ T Cells, the HLA Type of Donors With Reactive CD4+ T Cells, and the HLA Antigen Restriction of Each Epitope

\begin{tabular}{|c|c|c|c|c|c|c|}
\hline Peptide(s) & Donor & DRB I* & DRB- & DQB I* & HLA Antigen Restriction & Published Antigen Restriction \\
\hline & 12 & 03021,1503 & $3 * 01,5 * 01$ & 06 & DRBI*I5 or DRB5*0I & Pp65 $225-239$ DRI5 [23] \\
\hline \multirow[t]{2}{*}{ Pp65 $221-235$} & 08 & 13031,1503 & $3 * 02,3 * 02$ & 02,06 & & \\
\hline & 10 & 0701,1302 & $3^{*} 0301,4 * 0401$ & 0202,0604 & No cells available & \\
\hline Pp65 $285-299$ & 07 & 0401,0701 & $4 * 0 \mathrm{I}, 4 * 0 \mathrm{I}$ & 0303,03 & No cells available & $\mathrm{Pp} 5_{28 \mathrm{I}-295} \mathrm{DR} 4,7$ [II] \\
\hline \multirow[t]{4}{*}{$\mathrm{Pp} 65_{365-379}$} & 01 & 0901,11 & $3 * 00,4 * 01$ & 02,06 & & PP65 $361-376$ DRII [24] \\
\hline & 06 & 11,16 & $3 * 02,5 * 02$ & 0301,05 & & \\
\hline & 11 & 0102,1101 & $3 * 0202$ & 0301,0501 & DRBI*II & Pp65 $6161-375$ DRII [II] \\
\hline & 14 & 0402, I I 01 & $3 * 02,4 * 0103$ & 0301,0302 & & \\
\hline \multirow[t]{4}{*}{$\mathrm{Pp} 65_{489-503}$} & 06 & 11,16 & $3 * 02,5 * 02$ & 0301,05 & DRB3*02 & \\
\hline & 13 & $13,150 \mid$ & $3 * 02,5 * 01$ & 06 & & $\mathrm{PP} 65_{489-503}$ \\
\hline & 14 & 0402,1101 & $3 * 02,4 * 0103$ & 0301,0302 & & $\mathrm{DR} I \mathrm{I}, 3[24]$ \\
\hline & 17 & 13,1503 & $3 * 02,5 * 01$ & 06 & & Pp65 ${ }_{505-523}$ DR52 [II] \\
\hline & 06 & 11,16 & $3 * 02,5 * 02$ & 0301,05 & DQBI*0502 & Pp $65_{505-523}$ DRI [23] \\
\hline \multirow[t]{2}{*}{$\mathrm{PP} 65_{509-523}$} & 12 & 03021,1503 & $3 * 01,5 * 01$ & 06 & DRB3*0IOI & \\
\hline & 14 & 0402,1101 & $3 * 02,4 * 0103$ & 0301,0302 & No cells available & $\mathrm{PP} 65_{509-524} \mathrm{DR3}[24]$ \\
\hline
\end{tabular}

The HLA antigen restrictions identified are shown in bold 
Table I I: Proportion of Peripheral Blood CD4+ T Cells From 20 Healthy CMV-Seropositive Subjects Producing Intracellular IFN- $\gamma$ Following Stimulation With a Library of I20 CMV IE-I I5-mer Peptides I5 and Each of I2 Subpools Made Up of 10 Peptides

\begin{tabular}{|c|c|c|c|c|c|c|c|c|c|c|c|c|c|c|c|c|c|c|c|c|}
\hline & \multicolumn{20}{|c|}{ CD4+ T Cells Producing Intracellular IFN- $\gamma$ in Each Donor (\%) } \\
\hline & I & 2 & 3 & 4 & 5 & 6 & 7 & 8 & 9 & 10 & II & 12 & 13 & 14 & 15 & 16 & 17 & 18 & 19 & 20 \\
\hline $\begin{array}{l}\text { Library } \\
\text { Subpool }\end{array}$ & 0.02 & 0.04 & 0.01 & 0.03 & 0.02 & 0.14 & 0.03 & 0.05 & 0.01 & 0.02 & 0.08 & 0.06 & 0.04 & 0.13 & 0.09 & 0.02 & 0.05 & 0.02 & 0.00 & 0.10 \\
\hline i & 0.02 & 0.06 & 0.05 & 0.01 & 0.01 & 0.02 & 0.01 & 0.11 & 0.02 & 0.01 & 0.04 & 0.02 & 0.01 & 0.04 & 0.03 & 0.01 & 0.01 & 0.02 & 0.00 & 0.00 \\
\hline 2 & 0.02 & 0.01 & 0.05 & 0.02 & 0.01 & 0.03 & 0.01 & 0.00 & 0.02 & 0.01 & 0.02 & 0.03 & 0.01 & 0.02 & 0.04 & 0.01 & 0.01 & 0.02 & 0.00 & 0.01 \\
\hline 3 & 0.04 & 0.00 & 0.13 & 0.02 & 0.01 & 0.01 & 0.00 & 0.10 & 0.02 & 0.02 & 0.03 & 0.05 & 0.05 & 0.02 & 0.04 & 0.02 & 0.03 & 0.01 & 0.01 & 0.00 \\
\hline 4 & 0.06 & 0.05 & 0.01 & 0.04 & 0.01 & 0.06 & 0.03 & 0.05 & 0.04 & 0.01 & 0.03 & 0.04 & 0.01 & 0.05 & 0.03 & 0.02 & 0.02 & 0.02 & 0.00 & 0.03 \\
\hline 5 & 0.02 & 0.06 & 0.04 & 0.01 & 0.02 & 0.04 & 0.02 & 0.06 & 0.07 & 0.01 & 0.04 & 0.03 & 0.02 & 0.05 & 0.04 & 0.01 & 0.02 & 0.02 & 0.00 & 0.03 \\
\hline 6 & 0.03 & 0.00 & 0.04 & 0.01 & 0.02 & 0.15 & 0.01 & 0.04 & 0.00 & 0.02 & 0.05 & 0.04 & 0.03 & 0.08 & 0.03 & 0.02 & 0.01 & 0.02 & 0.02 & 0.01 \\
\hline 7 & 0.04 & 0.02 & 0.02 & 0.01 & 0.01 & 0.03 & 0.00 & 0.09 & 0.01 & 0.01 & 0.04 & 0.03 & 0.02 & 0.07 & 0.04 & 0.04 & 0.02 & 0.01 & 0.01 & 0.00 \\
\hline 8 & 0.03 & 0.03 & 0.00 & 0.01 & 0.00 & 0.02 & 0.01 & 0.03 & 0.03 & 0.01 & 0.05 & 0.01 & 0.01 & 0.03 & 0.03 & 0.01 & 0.00 & 0.00 & 0.01 & 0.03 \\
\hline 9 & 0.03 & 0.03 & 0.01 & 0.01 & 0.02 & 0.04 & 0.00 & 0.07 & 0.01 & 0.01 & 0.07 & 0.07 & 0.02 & 0.03 & 0.09 & 0.01 & 0.01 & 0.00 & 0.02 & 0.01 \\
\hline 10 & 0.03 & 0.05 & 0.01 & 0.00 & 0.02 & 0.02 & 0.02 & 0.06 & 0.02 & 0.01 & 0.04 & 0.03 & 0.01 & 0.05 & 0.02 & 0.02 & 0.02 & 0.01 & 0.01 & 0.01 \\
\hline II & 0.01 & 0.04 & 0.00 & 0.00 & 0.01 & 0.04 & 0.01 & 0.07 & 0.01 & 0.02 & 0.04 & 0.03 & 0.00 & 0.02 & 0.02 & 0.01 & 0.00 & 0.01 & 0.01 & 0.01 \\
\hline 12 & 0.01 & 0.03 & 0.01 & 0.04 & 0.02 & 0.02 & 0.00 & 0.10 & 0.03 & 0.01 & 0.04 & 0.04 & 0.02 & 0.01 & 0.04 & 0.00 & 0.02 & 0.01 & 0.00 & 0.01 \\
\hline
\end{tabular}

vaccines[29]. However, the lack of naturally occurring CD4+ T cell responses to IE-1 suggests that it may not be as useful as pp65 in a monovalent vaccine since both CD8+ and CD4+ responses to pp65 are frequently found in healthy CMV-seropositive positive subjects.

The characterization of pp65 and IE-1 epitopes will be valuable for monitoring patients treated with vaccines or adoptive immunotherapies, and these epitopes alone or in conjunction with HLA class I tetramers or pentamers can be used to follow the immune responses to these therapies. In addition, peptides, and HLA tetramers and pentamers can be used to assess the host immune response to CMV.

In conclusion, by screening healthy, CMV-seropositive subjects with pp65 and IE-1 peptides, we identified several new IE-1 epitopes and confirmed several other IE-1 and pp65 epitopes. Similar numbers of CMV pp65 and IE1 HLA class I epitopes were detected, and one region of IE1 was rich in HLA class I epitopes, especially those restricted to HLA-C*07. Although pp65 was rich in HLA class II epitopes, no IE-1 class II epitopes were identified.

\section{Competing interests}

The author(s) declare that they have no competing interests.

\section{Authors' contributions}

$\mathrm{MB}$, FMM and DFS conceived of the study; SLS and MB performed the research and collected data; SLS, MB, SS, FMM and DFS analyzed data; SA provided vital new reagents and participated in study design; SLS, DFS and MB drafted the manuscript; and all authors checked the final version of the manuscript.

\section{References}

I. Mocarski ES, Tan C: Cytomegaloviruses and their replication. In Fields Virology Volume 76. fourth edition. Edited by: Knipe DM and Howley PM. Philadelphia, Lippincott Williams and Wilkins; 200I:2629-2673.

2. Pass RF: Cytomegalovirus. In Fields Virology Volume 77. fourth edition. Edited by: Knipe DM and Howley PM. Philadelphia, Lippincott Williams and Wilkins; 200I:2675-2705.

3. Boeckh M, Leisenring W, Riddell SR, Bowden RA, Huang ML, Myerson D, Stevens-Ayers T, Flowers ME, Cunningham T, Corey L: Late cytomegalovirus disease and mortality in recipients of allogeneic hematopoietic stem cell transplants: importance of viral load and T-cell immunity. Blood 2003, 101:407-4I4.

4. Zaia JA, Sissons JG, Riddell S, Diamond DJ, Wills MR, Carmichael AJ Weekes MP, Gandhi M, La Rosa C, Villacres M, Lacey S, Markel S, Sun J: Status of Cytomegalovirus Prevention and Treatment in 2000. Hematology (Am Soc Hematol Educ Program ) 2000:339-355.

5. Walter EA, Greenberg PD, Gilbert MJ, Finch RJ, Watanabe KS, Thomas ED, Riddell SR: Reconstitution of cellular immunity against cytomegalovirus in recipients of allogeneic bone marrow by transfer of T-cell clones from the donor. N Engl J Med 1995, 333: 1038-1044.

6. Einsele H, Roosnek E, Rufer N, Sinzger C, Riegler S, Loffler J, Grigoleit $U$, Moris A, Rammensee HG, Kanz L, Kleihauer A, Frank F, Jahn G, Hebart $\mathrm{H}$ : Infusion of cytomegalovirus (CMV)-specific T cells for the treatment of CMV infection not responding to antiviral chemotherapy. Blood 2002, 99:3916-3922.

7. Berencsi K, Gyulai Z, Gonczol E, Pincus S, Cox WI, Michelson S, Kari L, Meric C, Cadoz M, Zahradnik J, Starr S, Plotkin S: A canarypox vector-expressing cytomegalovirus (CMV) phosphoprotein 65 induces long-lasting cytotoxic $T$ cell responses in human CMV-seronegative subjects. J Infect Dis 200I, I 83:I I7I-I I 79.

8. Wills MR, Carmichael AJ, Mynard K, Jin X, Weekes MP, Plachter B, Sissons JG: The human cytotoxic T-lymphocyte (CTL) response to cytomegalovirus is dominated by structural protein pp65: frequency, specificity, and T-cell receptor usage of pp65-specific CTL. J Virol 1996, 70:7569-7579.

9. Kern F, Surel IP, Faulhaber N, Frommel C, Schneider-Mergener I, Schonemann C, Reinke P, Volk HD: Target structures of the CD8(+)-T-cell response to human cytomegalovirus: the 72kilodalton major immediate-early protein revisited. J Virol 1999, 73:8179-8184.

10. McLaughlin-Taylor E, Pande H, Forman SJ, Tanamachi B, Li CR, Zaia JA, Greenberg PD, Riddell SR: Identification of the major late human cytomegalovirus matrix protein pp65 as a target antigen for CD8+ virus-specific cytotoxic T lymphocytes. J Med Virol 1994, 43: I03-I I0.

II. Kern F, Bunde T, Faulhaber N, Kiecker F, Khatamzas E, Rudawski IM, Pruss A, Gratama JW, Volkmer-Engert R, Ewert R, Reinke P, Volk HD, Picker LJ: Cytomegalovirus (CMV) phosphoprotein 65 
makes a large contribution to shaping the $T$ cell repertoire in CMV-exposed individuals. J Infect Dis 2002, 185:1709-1716.

12. Davignon JL, Clement D, Alriquet J, Michelson S, Davrinche C: Analysis of the proliferative $T$ cell response to human cytomegalovirus major immediate-early protein (IEI): phenotype, frequency and variability. Scand f Immunol 1995, 41:247-255.

13. Diamond DJ, York J, Sun JY, Wright CL, Forman SJ: Development of a candidate HLA A*020I restricted peptide-based vaccine against human cytomegalovirus infection. Blood 1997, 90:175I-1767.

14. Provenzano M, Lim JB, Mocellin S, Monsurro V, Bettinotti M, Marincola FM, Stroncek DF: The matrix protein pp65(34I-350): a peptide that induces ex vivo stimulation and in vitro expansion of CMV-specific CD8+ T cells in subjects bearing either HLA-A*2402 or A*0 I 0 I allele. Transfusion 2003, 43:I567-I574.

15. Kern F, Surel IP, Brock C, Freistedt B, Radtke H, Scheffold A, Blasczyk R, Reinke P, Schneider-Mergener J, Radbruch A, Walden P, Volk HD: T-cell epitope mapping by flow cytometry. Nat Med 1998, 4:975-978

16. Maecker HT, Dunn HS, Suni MA, Khatamzas E, Pitcher CJ, Bunde T, Persaud N, Trigona W, Fu TM, Sinclair E, Bredt BM, McCune JM, Maino VC, Kern F, Picker LJ: Use of overlapping peptide mixtures as antigens for cytokine flow cytometry. J Immunol Methods 200I, 255:27-40.

17. Plotkin SA, Furukawa T, Zygraich N, Huygelen C: Candidate cytomegalovirus strain for human vaccination. Infect Immun I 975, I 2:52I-527.

18. ROWE WP, HARTLEY JW, WATERMAN S, TURNER HC, HUEBNER RJ: Cytopathogenic agent resembling human salivary gland virus recovered from tissue cultures of human adenoids. Proc Soc Exp Biol Med 1956, 92:41 8-424.

19. Khan N, Shariff N, Cobbold M, Bruton R, Ainsworth JA, Sinclair AJ, Nayak L, Moss PA: Cytomegalovirus seropositivity drives the CD8 T cell repertoire toward greater clonality in healthy elderly individuals. J Immunol 2002, 169:1984-1992.

20. Gavin MA, Gilbert MJ, Riddell SR, Greenberg PD, Bevan MJ: Alkali hydrolysis of recombinant proteins allows for the rapid identification of class I MHC-restricted CTL epitopes. I Immunol 1993, I 5 I:397|-3980.

21. Longmate J, York J, La Rosa C, Krishnan R, Zhang M, Senitzer D, Diamond DJ: Population coverage by HLA class-I restricted cytotoxic T-lymphocyte epitopes. Immunogenetics 200I, 52:I65-173.

22. Retiere C, Prod'homme V, Imbert-Marcille BM, Bonneville M, Vie H, Hallet MM: Generation of cytomegalovirus-specific human Tlymphocyte clones by using autologous B-lymphoblastoid cells with stable expression of pp65 or IE I proteins: a tool to study the fine specificity of the antiviral response. J Virol 2000 , 74:3948-3952.

23. Li PG, Bottone L, Ivaldi F, Pelizzoli R, Del Galdo F, Lozzi L, Bracci L, Loregian A, Palu G, De Palma R, Einsele H, Manca F: Identification of new Th peptides from the cytomegalovirus protein pp65 to design a peptide library for generation of CD4 T cell lines for cellular immunoreconstitution. Int Immunol 2004, 16:635-642.

24. Khattab BA, Lindenmaier W, Frank R, Link H: Three T-cell epitopes within the C-terminal 265 amino acids of the matrix protein pp65 of human cytomegalovirus recognized by human lymphocytes. J Med Virol 1997, 52:68-76.

25. Sylwester AW, Mitchell BL, Edgar JB, Taormina C, Pelte C, Ruchti F, Sleath PR, Grabstein KH, Hosken NA, Kern F, Nelson JA, Picker LJ: Broadly targeted human cytomegalovirus-specific CD4+ and CD8+ $T$ cells dominate the memory compartments of exposed subjects. J Exp Med 2005, 202:673-685.

26. Ghei M, Stroncek DF, Provenzano M: Analysis of memory T lymphocyte activity following stimulation with overlapping HLA-A*2402, A*0101 and Cw*0402 restricted CMV pp65 peptides. I Transl Med 2005, 3:23.

27. Gallez-Hawkins G, Villacres MC, Li X, Sanborn MC, Lomeli NA, Zaia JA: Use of transgenic HLA A*020I/Kb and HHD II mice to evaluate frequency of cytomegalovirus IEI-derived peptide usage in eliciting human CD8 cytokine response. J Virol 2003, 77:4457-4462.

28. Schleiss M: Progress in cytomegalovirus vaccine development. Herpes 2005, I 2:66-75.

29. Bunde T, Kirchner A, Hoffmeister B, Habedank D, Hetzer R, Cherepnev G, Proesch S, Reinke P, Volk HD, Lehmkuhl H, Kern F: Protec- tion from cytomegalovirus after transplantation is correlated with immediate early I-specific CD8 T cells. J Exp Med 2005, 201:103I-1036.

30. Solache A, Morgan CL, Dodi Al, Morte C, Scott I, Baboonian C, Zal $B$, Goldman J, Grundy JE, Madrigal JA: Identification of three HLAA*020I-restricted cytotoxic T cell epitopes in the cytomegalovirus protein pp65 that are conserved between eight strains of the virus. J Immunol 1999, 163:5512-55।8.
Publish with Bio Med Central and every scientist can read your work free of charge

"BioMed Central will be the most significant development for disseminating the results of biomedical research in our lifetime. "

Sir Paul Nurse, Cancer Research UK

Your research papers will be:

- available free of charge to the entire biomedical community

- peer reviewed and published immediately upon acceptance

- cited in PubMed and archived on PubMed Central

- yours - you keep the copyright

Submit your manuscript here:

http://www.biomedcentral.com/info/publishing_adv.asp
BioMedcentral 